\title{
Recent Advances in Carbon Dioxide Utilization
}

\author{
Zhien Zhang ${ }^{\mathrm{a}}$, Shu-Yuan Pan ${ }^{\mathrm{b}}$, Hao Li ${ }^{\mathrm{c}}$, Jianchao Cai ${ }^{\mathrm{d}}$, Abdul Ghani Olabi ${ }^{\mathrm{e}, \mathrm{f}, *}$, Edward \\ John Anthony, ,*, Vasilije Manovic ${ }^{\mathrm{g}}$
}

${ }^{a}$ William G. Lowrie Department of Chemical and Biomolecular Engineering, The Ohio State University, Columbus, Ohio 43210, USA

${ }^{\mathrm{b}}$ Department of Bioenvironmental Systems Engineering, National Taiwan University, Taipei City 10617, Taiwan

${ }^{c}$ Department of Chemistry and the Oden Institute for Computational Engineering and Sciences, The University of Texas at Austin, 105 E. 24th Street, Stop A5300, Austin, Texas 78712, USA

${ }^{\mathrm{d}}$ Hubei Subsurface Multi-Scale Imaging Key Laboratory, Institute of Geophysics and Geomatics, China University of Geosciences, Wuhan 430074, China

${ }^{\mathrm{e}}$ Mechanical Engineering and Design, School of Engineering and Applied Science, Aston University, Aston Triangle, Birmingham, B4 7ET, UK

${ }^{\mathrm{f}}$ Sustainable and Renewable Energy Engineering Department, University of Sharjah, Sharjah, United Arab Emirates

${ }^{\mathrm{g}}$ Centre for Combustion and CCS, School of Energy, Environment and Agrifood, Cranfield University, Bedford, Bedfordshire MK43 0AL, UK

* Corresponding authors: aolabi@ sharjah.ac.ae (A.G. Olabi);

b.j.anthony@cranfield.ac.uk (E.J. Anthony)

\begin{abstract}
Carbon dioxide $\left(\mathrm{CO}_{2}\right)$ is the major contributor to greenhouse gas $(\mathrm{GHG})$ emissions and the main driver of climate change. Currently, $\mathrm{CO}_{2}$ utilization is increasingly attracting interest in processes like enhanced oil recovery and coal bed methane and it has the potential to be
\end{abstract}


used in hydraulic fracturing processes, among others. In this review, the latest developments in $\mathrm{CO}_{2}$ capture, utilization, conversion, and sequestration are examined through a multi-scale perspective. The diverse range of $\mathrm{CO}_{2}$ utilization applications, including mineralization, biological utilization, food and beverages, energy storage media, and chemicals, is comprehensively presented. We also discuss the worldwide research and development of $\mathrm{CO}_{2}$ utilization projects. Lastly, we examine the key challenges and issues that must be faced for pilot-scale and industrial applications in the future. This study demonstrates that $\mathrm{CO}_{2}$ utilization can be a driver for the future development of carbon capture and utilization technologies. However, considering the amount of $\mathrm{CO}_{2}$ produced globally, even if it can be reduced in the near- to mid-term future, carbon capture and storage will remain the primary strategy and, so, complementary strategies are desirable. Currently, the main $\mathrm{CO}_{2}$ utilization industry is enhanced oil and gas recovery, but considering the carbon life cycle, these processes still add $\mathrm{CO}_{2}$ to the atmosphere. In order to implement other $\mathrm{CO}_{2}$ utilization technologies at a large scale, in addition to their current technical feasibility, their economic and societal viability is critical. Therefore, future efforts should be directed toward reduction of energy penalties and costs, and the introduction of policies and regulation encouraging carbon capture, utilization and storage, and increasing the public acceptance of the strategies in a complementary manner.

Keywords: $\mathrm{CO}_{2}$ utilization; Carbon Capture, Utilization and Sequestration (CCUS); Carbon Capture and Storage (CCS); Climate change 


\section{Introduction}

Carbon dioxide $\left(\mathrm{CO}_{2}\right)$, as one of the greenhouse gases (GHGs) emissions emitted by human activities, is the main cause for climate change [1]. As of 2018, global $\mathrm{CO}_{2}$ emissions had increased to $37.1 \mathrm{Gt}$, of most of which still comes from the combustion of fossil fuels from a wide range of industrial processes and transportation. Additional increase in anthropogenic $\mathrm{CO}_{2}$ production in 2019 appears likely due to the sustained use of oil and natural gas and the strong increases projected to drive the worldwide economy [2]. According to data from the National Oceanic and Atmospheric Administration / Earth System Research Laboratory, global $\mathrm{CO}_{2}$ emissions are steadily increasing, and $\mathrm{CO}_{2}$ concentration in the atmosphere has reached 411 ppm, a new record high [3]. BP's Energy Outlook claims that $\mathrm{CO}_{2}$ emissions from energy use will continue to rise through the next several years, increasing by $\sim 10 \%$ by 2040 in the evolving transition scenario [4]. In response to these dramatic increases, the Intergovernmental Panel on Climate Change (IPCC) recently recommended limiting global warming to $1.5{ }^{\circ} \mathrm{C}$ instead of $2.0{ }^{\circ} \mathrm{C}$ to reduce catastrophic climate change issues [5]. In consequence, finding methods to convert $\mathrm{CO}_{2}$ to useful commodities could spur the development of novel techniques, products, and industries, and help to reduce the climate-altering emissions. Several international agreements have been reached, considering that carbon capture, utilization and sequestration (CCUS)-an integration of carbon capture and utilization (CCU) and carbon capture and storage (CCS)-is essential to cut $\mathrm{CO}_{2}$ emissions in a sustainable way to limit the severity of climate change [6-8].

In a CCUS process, $\mathrm{CO}_{2}$ is first captured from exhaust gases of fossil fuel combustion and purified to deliver a high-purity $\mathrm{CO}_{2}$ stream, after which it can either be sequestered or converted to valuable products with environmental, economic, and social benefits. $\mathrm{CO}_{2}$ can be physically and chemically employed in the various fields of chemical, biological, and food processes, which are at different stages of development and demonstration. 
However, we are drastically failing in meeting our targets of GHG reduction, which can be seen in terms of arctic changes and ocean acidification $[9,10]$, and we will need every option, including CCS for gas and coal projects, and CCU in the near future to reduce energy and resource consumption, and improve innovation and competitiveness.

Here, we first present the trends and status of research on carbon dioxide utilization (CDU). We review a diverse range of CDU technologies, including mineralization, biological utilization, food and beverages, energy storage, and chemicals production. We also illustrate the current research and development (R\&D) CDU projects worldwide. Lastly, we discuss the market, policies, and challenges in CDU, and then propose priority research directions for the future.

\section{$2 \mathrm{CO}_{2}$ Utilization Technologies}

In the CCUS framework, $\mathrm{CO}_{2}$ is utilized in a variety of ways, mainly mineral carbonation, physical and chemical methods, which are discussed below.

\subsection{Fuels and Chemicals}

$\mathrm{CO}_{2}$ can be utilized as a building block, or feedstock for the sustainable production of chemicals or even fuels, providing extra added value and potentially sequestrating $\mathrm{CO}_{2}$ [11]. The common products made from $\mathrm{CO}_{2}$ include urea, formic acid, methanol, cyclic carbonates, and salicylic acid [12, 13]. Among them, some products such as formic acid should be preferentially considered because they have the largest potential for $\mathrm{CO}_{2}$ emission reduction [14]. To compete with fossil fuel-derived products, the economic feasibility studies are very important, which consider uncertainties in market due to government policies and legislations (e.g., carbon tax).

\subsubsection{Electro-catalytic conversion}

There are complicated pathways to convert $\mathrm{CO}_{2}$ into chemicals or fuels including electrochemical, thermocatalytic, photochemical, biochemical, and hybrid methods [15]. 
Electro-catalytic methods for converting $\mathrm{CO}_{2}$ to commercially-valued products, including carbon monoxide [16], methane [17], methanol [18], and hydrocarbons [19], have been broadly studied using both experimental and theoretical methods. Liquid-phase electrocatalysis has a relatively complex mechanism, with very different reaction intermediates and final products, and various catalytic systems used. In particular, both heterogeneous metallic catalysts and enzymes have been found to be suitable for such reactions [20]. Here, the catalytic site effect has been shown to be particularly important to ensure selective $\mathrm{CO}_{2}$ reduction, but usually more easily achieved, compared to the competing hydrogen evolution reaction [21]. The mechanistic insights for $\mathrm{Au}, \mathrm{Ag}$ and $\mathrm{Cu}$ have been elucidated by density functional theory (DFT) calculations, while inactivity of Pt is still not explained. Interestingly, unlike the other metallic catalysts, $\mathrm{Cu}$ selectively converts $\mathrm{CO}_{2}$ to hydrocarbons such as methane and ethylene [22]. Using DFT calculations, Nie et al. [23] have suggested a series of possible pathways for the selective $\mathrm{CO}_{2}$ reduction on $\mathrm{Cu}$. For a rational catalyst design, Hansen et al. [24] have developed a volcano-shaped contour plot to describe the trends of the $\mathrm{CO}_{2}$ electro-reduction, with the $\mathrm{CO}$ and $\mathrm{COOH}^{-}$adsorption energies as the reaction descriptors (Fig. 1(a-c)). With more DFT-calculated thermodynamic parameters, Cheng et al. [25] further designed a series of Au- and Ag-based single-atom catalysts (Au or Ag surface atoms replaced by "strong-binding" transition metals) that could theoretically convert $\mathrm{CO}_{2}$ to hydrocarbons. Ma et al. [26] and Ulissi et al. [27] used the machine learning method (i.e., artificial neural networks [28]) for a largerscale catalyst screening of alloy surfaces (Fig. 1(d)). Specifically, they evaluated various binding sites on NiGa alloys and found highly active sites (Fig. 1(e)). Also, based on the recently developed "tunability" theory of adsorbate (e.g., $\mathrm{H}$ and $\mathrm{CO}$ ) bindings with the atomic ensemble effects, it is expected that some new types of alloy catalysts may be highly active and selective in $\mathrm{CO}_{2}$ electro-reduction processes. More recently, new catalytic systems have also been evaluated for $\mathrm{CO}_{2}$ electro-reduction, including graphene and defected graphene [29], nitrogen-doped graphene [30], transition metal sulfides [31], 
core@shell materials [32], complexes [33], supramolecular porous organic cages [34], and metallic/oxide nanosheets [35]. These studies have shown that new materials can be applied for $\mathrm{CO}_{2}$ electro-reduction with relatively high activity, selectivity, and stability. However, the more expensive and exotic the precursor materials are, their use in any particular scheme at an industrial scale is limited.

Although several studies have been reported for $\mathrm{CO}_{2}$ electro-reduction on catalytic surfaces, there are still challenges that limit further development. These include uncertain kinetic parameters for the various reactions [36], mismatching between current theories and experiments [37], and the formation of unstable metallic structures during catalysis [38]. These issues result mainly from the lack of in situ observation on the reaction mechanisms and active sites during experimentation. Though theoretical studies provide insights into the reaction mechanisms and new catalyst design, there are limits in the modeling of the systems. For example, water and solvation effects have been found to be particularly important for mechanistic studies of $\mathrm{CO}_{2}$ reduction using DFT. However, most previous modeling studies have not considered the presence of water molecules, which leads to higher uncertainty and discrepancies between model predictions and experiments. This not only hinders the rational design of highly active and selective $\mathrm{CO}_{2}$ reduction catalysts, but also limits the applications of $\mathrm{CO}_{2}$ electro-reduction in industries. However, they can be addressed with further theoretical studies and in situ experiments. 

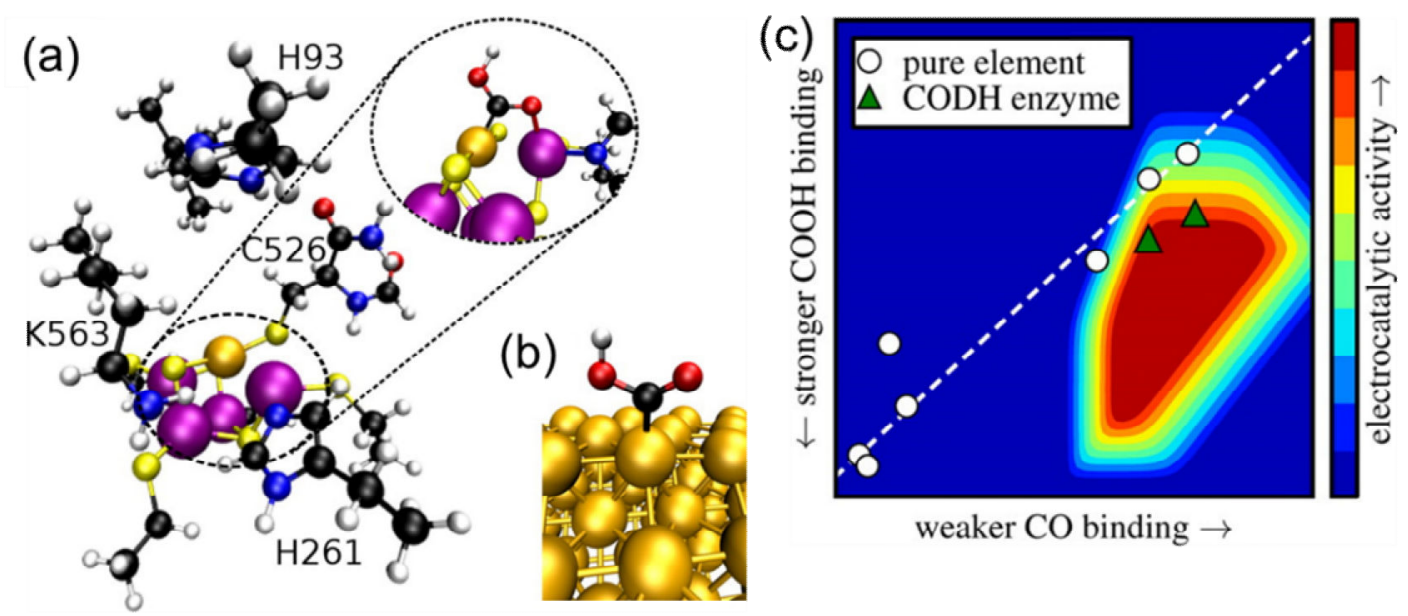

weaker $\mathrm{CO}$ binding $\rightarrow$
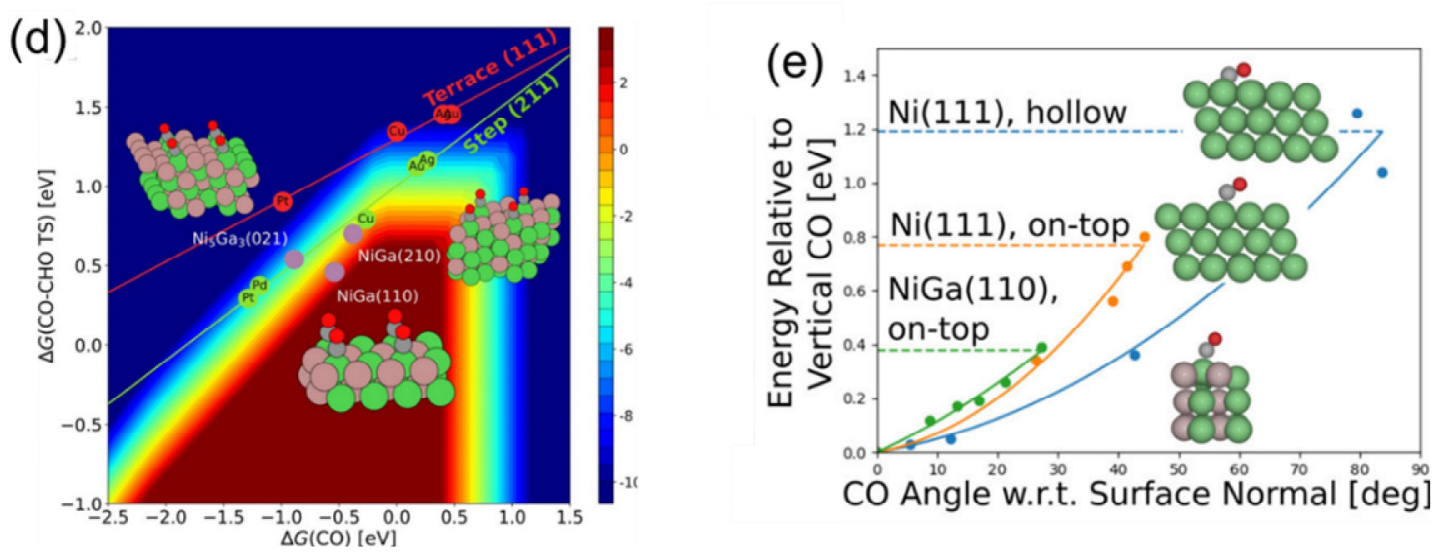

Fig. 1 Models of the active site for $\mathrm{CO}_{2}$ electro-catalytic reduction on (a) enzyme and (b) $\mathrm{Au}$ surface. (c) Volcano activity plot for $\mathrm{CO}_{2}$ electro-catalytic reduction at a $0.35 \mathrm{~V}$ overpotential. The data were obtained from the (211) stepped sites of transition metals. (d) Predicted activity of transition metal and the NiGa sites. (e) Rotation energy of $\mathrm{CO}$ on $\mathrm{Ni}$ and $\mathrm{NiGa}$ (110). Reprinted with permission from Refs. [24, 26].

\subsubsection{Plastics}

$\mathrm{CO}_{2}$-based polymers used as the raw materials for plastics are potentially more environmentally friendly, and hence have attracted much industrial attention [39]. They are produced by copolymerization of hydrocarbons and $\mathrm{CO}_{2}$ (about 31-50\%), which reduces the consumption of petrochemical products [40]. $\mathrm{CO}_{2}$ was first used by Inoue et al. [41] in 1969 in the sequential copolymerization process with epoxides to form high-molecularweight aliphatic polycarbonates, as illustrated in Fig. 2. Importantly, the polymerization 
reaction needs to be catalyzed. Therefore, the production of cheap and efficient catalysts is the key to future developments. The commonly used catalysts in the copolymerization between $\mathrm{CO}_{2}$ and the epoxides include homogeneous, heterogeneous and supported catalysts, and are mainly organometallic compounds [42]. Fig. 3 shows the representative homogeneous and heterogeneous catalysts for the copolymerization process [40, 43]. Among them, $\beta$-diiminate (BDI) zinc complexes [44-46], rare earth metal complexes [47, 48], metalloporphyrin complexes [49], and Schiff-base metal complexes $[50,51]$ are widely employed in current research. A good copolymerization catalytic system should have high selectivity activity, and be easy to prepare, safe and nontoxic [52]. The large-scale application of $\mathrm{CO}_{2}$ copolymers is still limited due to relatively low catalytic activity and poor thermal and mechanical properties.

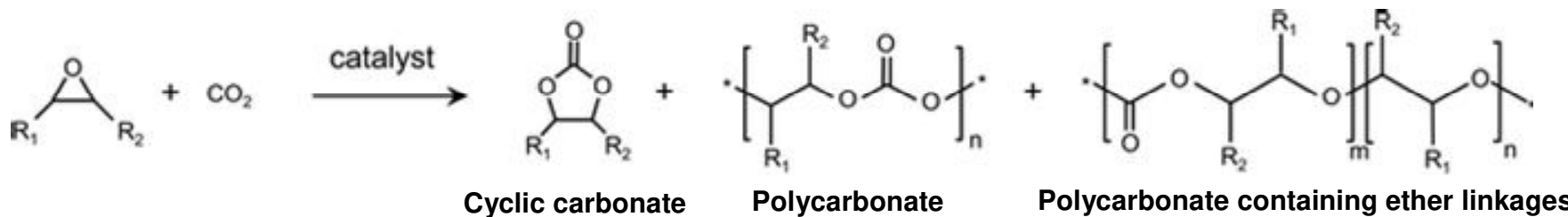

Fig. 2 Possible products from $\mathrm{CO}_{2}$ reacting with epoxides. Reprinted with permission from Ref. [53].

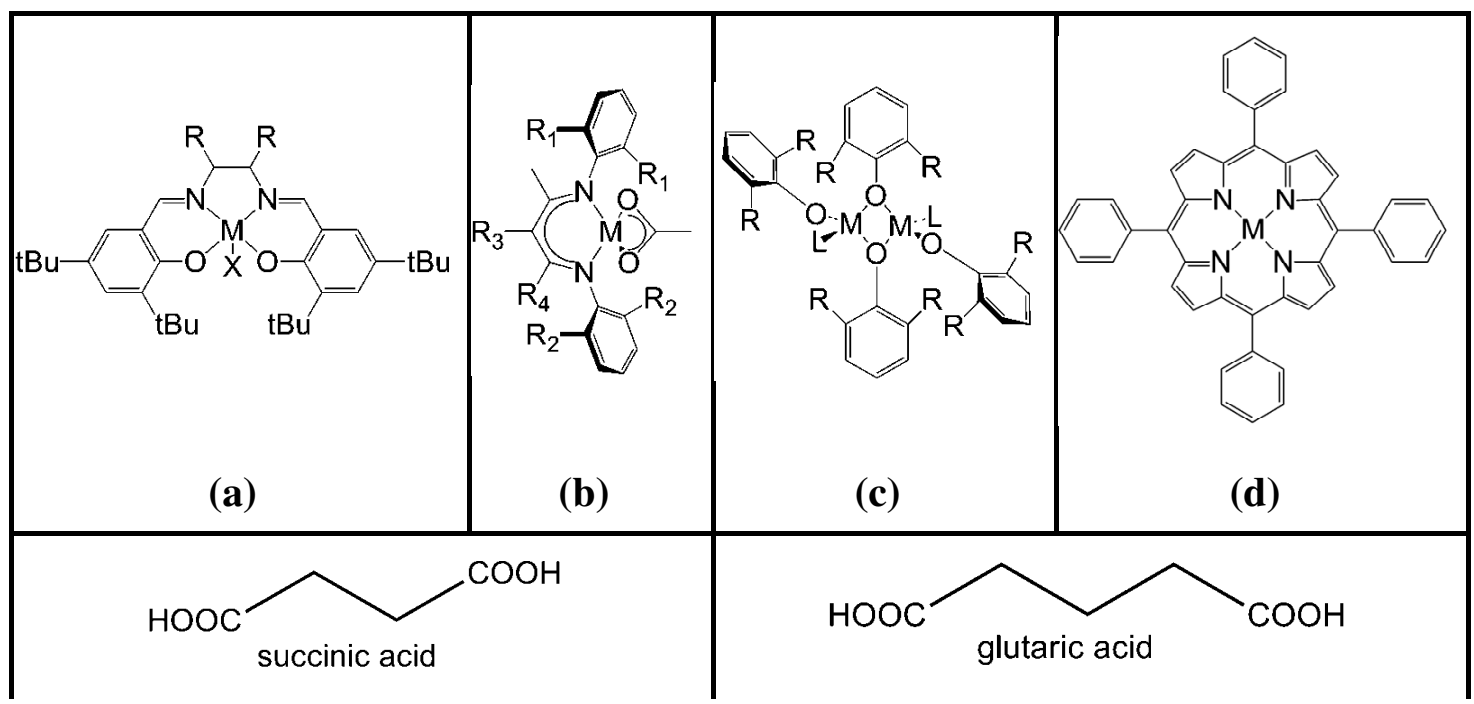




\begin{tabular}{|c|c|c|c|} 
(e) & (f) \\
(g) & (h) \\
\hline
\end{tabular}

Fig. 3 Common homogeneous catalyst systems (a) salen, (b) $\beta$-diiminate, (c) phenoxides, (d) porphyrin; and acids used in the heterogeneous catalyst synthesis (e) succinic acid $\left(\mathrm{C}_{4}\right)$, (f) glutaric acid $\left(\mathrm{C}_{5}\right)$, (g) adipic acid $\left(\mathrm{C}_{6}\right)$, (h) pimelic acid $\left(\mathrm{C}_{7}\right)$. Reprinted with permission from Ref. [40].

In past decades, there have been a large number of experimental and theoretical studies on the reaction mechanisms, catalytic efficiency, and the applications of polymers [53-57]. Polyoxymethylene (POM) is a polycondensation polymer which can be fabricated from $\mathrm{CO}_{2}$ through the intermediate, formaldehyde, and serve as an alternative to polyethylene and polypropylene. Although POM is more expensive than other polymers, it has better mechanical properties that can compensate for the higher price in certain applications [58, 59]. Furthermore, polyethercarbonate polyols (PECPs) are produced by the copolymerization of $\mathrm{CO}_{2}$ and propylene oxide (PO), which were successfully used for preparing polyurethane (PU) foams by Langanke et al. [60] as demonstrated in Fig. 4(a). As shown in Fig. 4(b), PU foams prepared in this study show the same thermal stability when compared with the conventional PU materials. This implies that the large-scale polyethercarbonate polyols applications for PU production offer a new way to utilize carbon. One major concern for using $\mathrm{CO}_{2}$-derived polymers is the following decomposition of these polymers over several decades, releasing $\mathrm{CO}_{2}$ back to the atmosphere [39].

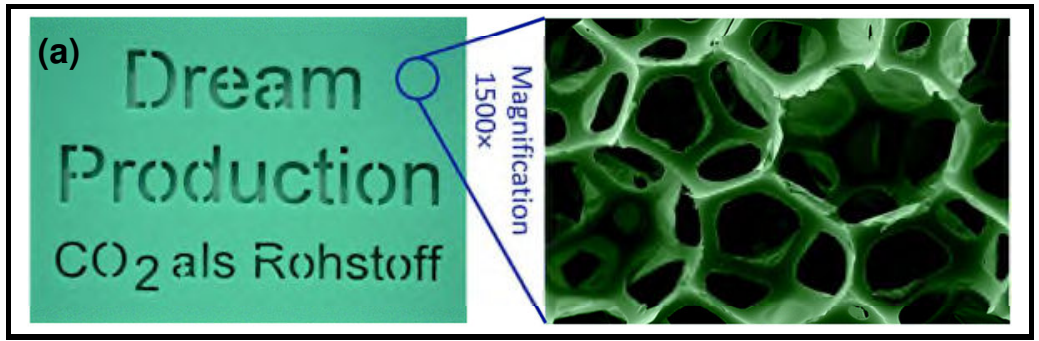




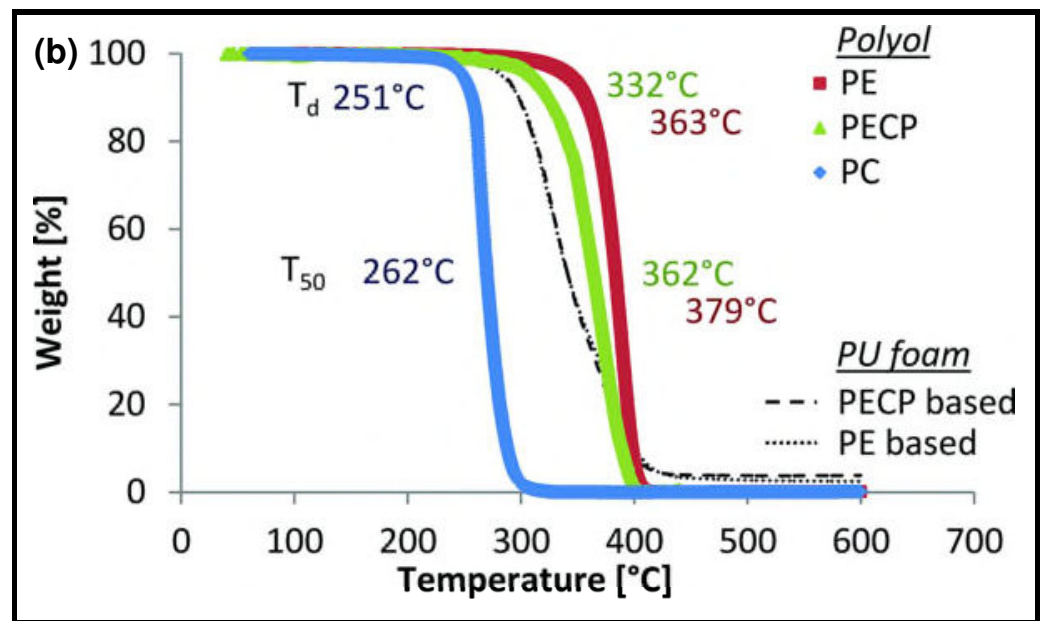

Fig. 4 (a) Scanning electron micrograph of a flexible PU foam produced by toluene diisocyanate (TDI) and PECP $\left(10.5 \mathrm{wt} \% \mathrm{CO}_{2}\right)$, (b) thermal stability of PECP and polyether (PE), and PU foams based on them; Reprinted with permission from Ref. [60].

\subsubsection{Urea}

According to the recent IPCC report [61], agriculture activities accounted for $23 \%$ of all anthropogenic GHGs emissions globally during 2007-2016. Fertilizers are widely used in the agricultural and forestry fields, and the synthetic nitrogen fertilizer accounts for around $70 \%$ of the global fertilizer use which is produced via reacting $\mathrm{CO}_{2}$ with anhydrous ammonia during the synthesis [62]. Urea is a neutral fertilizer with the highest nitrogen content up to $46 \%$, which is simple to store and does not present fire risks for the long-term storage. The most common method for producing urea is the steam reformation of natural gas which generates $\mathrm{CO}_{2}$ and ammonia (see Eqs. (1-2)).

$$
\begin{gathered}
\mathrm{N}_{2}+3 \mathrm{H}_{2} \rightarrow 2 \mathrm{NH}_{3} \\
\mathrm{CO}_{2}+2 \mathrm{NH}_{3} \leftrightarrow \mathrm{NH}_{2} \mathrm{CONH}_{2}+\mathrm{H}_{2} \mathrm{O}
\end{gathered}
$$

However, these urea fertilizers are normally derived from fossil fuels which also release net $\mathrm{CO}_{2}$ emissions during the process of synthesis. At the same time, the feedstocks of fossil fuels are limited, and the gradual depletion inevitably reduces the supply security. The integrated systems of urea production and utilization using both fossil and renewable 
energy have been proposed and reported. Gilbert et al. [63] came up with a novel process using $\mathrm{H}_{2}$ rich syngas from biomass gasification instead of natural gas reforming during ammonia production, which reduced $65 \%$ of the GHG emissions compared with the conventional process. Koohestanian et al. [64] proposed a new design process of urea production from the power plants flue gas, and $\mathrm{CO}_{2}, \mathrm{~N}_{2}$, and $\mathrm{H}_{2} \mathrm{O}$ from the tail gas were utilized in the process. The intensified approach decreased the environmental risks and produced the urea more than $1.68 \mathrm{t} / \mathrm{t} \mathrm{CO}_{2}$. In addition, a concept of Blue Urea has been proposed which converted the captured $\mathrm{CO}_{2}$ into valuable chemicals $[62,65]$. In this process, the ammonium carbamate was produced via the reaction between $\mathrm{CO}_{2}$ and $\mathrm{NH}_{3}$ into the organic solvents, i.e. 1-propanol, ethanol or N, N-dimethylformamide (DMF). Then, it was utilized to produce urea in the present of various catalysts. However, these integrated systems for urea production are still in the conceptual stage and operated under the controlled conditions. They need to be evaluated in the real conditions before the scaling up to commercial applications since the interactions among fertilizer, soil and corps are complex.

Although $\mathrm{CO}_{2}$ can be widely converted to chemicals, liquid fuels and polymers, the $\mathrm{CO}_{2}$ conversion processes consume a lot of energy. Renewable solar, wind, wave, hydropower, geothermal energy, and waste heat from plants should be the first consideration. For instance, the solar thermochemical technology is proved to be a novel and feasible pathway for $\mathrm{CO}_{2}$ conversion using solar energy. The excessive solar electricity could be employed for the synthesis of renewable fuels during the summer which can be used during the winter. In terms of sustainable large-scale $\mathrm{CO}_{2}$ utilization, the commodity products of these conversion processes should be economically viable and in high demand. Meanwhile, it is essential to evaluate the economic feasibility and energy balance of the conversion processes. 


\subsection{Mineralization}

Industrial $\mathrm{CO}_{2}$ emissions can be effectively utilized through mineralization processes (so-called accelerated carbonation) to form various products and/or carbonate precipitates, as it is a thermodynamically favorable reaction. A variety of feedstocks, such as natural silicate ores [66] and alkaline solid wastes $[67,68]$ can be utilized in $\mathrm{CO}_{2}$ mineralization processes. Recently, mineralization using alkaline residues has become an attractive method for direct and indirect decrease in $\mathrm{CO}_{2}$ emissions from industries and power plants $[69,70]$. Despite the very large $\mathrm{CO}_{2}$ capture capacity using natural ores, mineralization using alkaline solid wastes has other merits, such as low feedstock cost and availability near the source of $\mathrm{CO}_{2}$. Mineralization can be achieved through four main approaches [71]: (i) direct carbonation, i.e., the reaction of $\mathrm{CO}_{2}$ with alkaline slurry or mixture in a single reactor; (ii) indirect carbonation, i.e., the extraction of ions of interest for the production of high-purity chemicals such as $\mathrm{CaCO}_{3}$ and $\mathrm{K}_{2} \mathrm{SO}_{4}$ via multiple steps; (iii) carbonation curing, i.e., the use of $\mathrm{CO}_{2}$ for curing of cement-based materials to enhance their strength and durability; and (iv) electrochemical mineralization , i.e., the use of an electrochemical cell to mineralize $\mathrm{CO}_{2}$ while producing hydrogen or electricity. A number of large-scale $\mathrm{CO}_{2}$ mineralization demonstrations have been carried out, and critically reviewed from technical and engineering-science perspectives [72].

Available alkaline solid residues include iron and steel slags [73, 74], incinerator ashes [75], fossil fuel residues [76, 77], cement and concrete waste [78, 79], mining and mineral processing waste $[80,81]$, and pulp/paper mill waste $[82,83]$. They typically contain a large amount of alkaline earth metals (i.e., calcium and magnesium), which can serve as suitable feedstocks for $\mathrm{CO}_{2}$ mineralization. To examine the performance of different mineralization processes, Pan et al. [84] developed an integrated thermal analysis method and determined the relationship between carbonation conversion and weight gain for different types of solid residues. The integrated thermal analysis method accurately 
quantifies the weight of reaction products after mineralization based on the interpretation of the thermogravimetric and derivative thermogravimetric (TG-DTG) plots. As shown in Fig. 5(a), a relationship between carbonation conversion and weight gain of alkaline residues can be easily identified and compared. In general, a carbonation conversion above $85 \%$ for solid residues is acceptable to achieve waste stabilization and $\mathrm{CO}_{2}$ fixation [85]. It should be noted that the carbonation conversion of alkaline residues represents the ratio of the actual amount to the theoretical maximum amount of $\mathrm{CO}_{2}\left(\right.$ denoted as $\left.\mathrm{ThCO}_{2}\right)$ that can be mineralized. According to the chemical compositions of solid residues, one can estimate the $\mathrm{ThCO}_{2}$ ( $\mathrm{kg} \mathrm{CO} 2$ per $\mathrm{kg}$ of solid residue on dry basis) by Steinour's equation [86]:

$$
\begin{aligned}
& \mathrm{ThCO}_{2}(\%)=0.785\left(\mathrm{CaO}-0.56 \mathrm{CaCO}_{3}-0.7 \mathrm{SO}_{3}\right)+1.091 \mathrm{MgO}+1.420 \mathrm{Na}_{2} \mathrm{O}+ \\
& 0.935 \mathrm{~K}_{2} \mathrm{O}
\end{aligned}
$$

where $\mathrm{CaO}, \mathrm{SO}_{3}, \mathrm{MgO}, \mathrm{Na}_{2} \mathrm{O}$, and $\mathrm{K}_{2} \mathrm{O}$ are their weight fractions (per kg solid residue) obtained via $\mathrm{X}$-ray fluorescence (XRF). $\mathrm{CaCO}_{3}$ is the weight fraction analyzed by integrated thermal analysis.
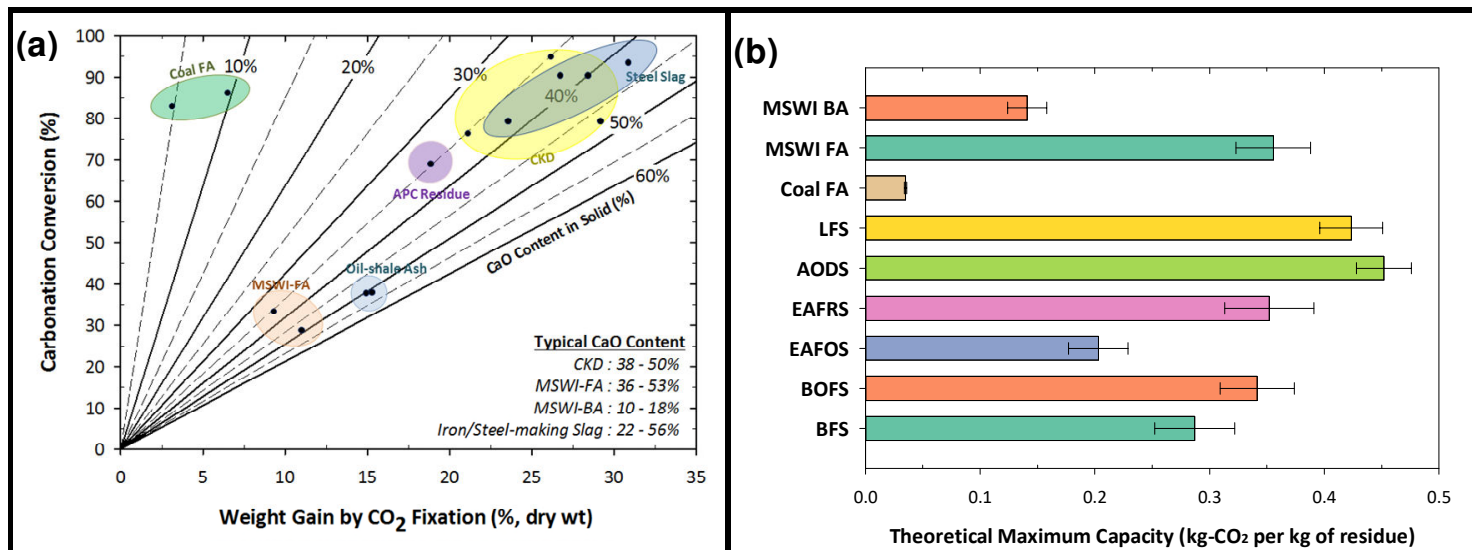

Fig. 5 (a) Relationship of carbonation conversion and weight gain for various solid residues. Acronyms: cement kiln dust (CKD), municipal solid waste incinerator (MSWI), fly ash (FA), and bottom ash (BA). Reprinted with permission from Ref. [84]. (b) Theoretical maximum capacity of $\mathrm{CO}_{2}$ mineralization for different solid residues (with a $95 \%$ confidence interval). Reprinted with permission from Ref. [87]. Acronyms: ladle furnace 
slag (LFS), argon oxygen decarburization slag (AODS), electric arc furnace reducing slag (EAFRS), electric arc furnace oxidizing slag (EAFOS), basic oxygen furnace slag (BOFS), and blast furnace slag (BFS).

Fig. 5(b) shows the values of $\mathrm{ThCO}_{2}$ for different solid residues based on integrated thermal analysis and Steinour's equation. In most cases, $\mathrm{ThCO}_{2}$ values for alkaline solid residues are proportional to the percent of calcium-bearing compounds. For instance, argon oxygen decarburization slags have a theoretical maximum capacity in the range of $0.43-$ $0.48 \mathrm{~kg} \mathrm{CO}_{2} / \mathrm{kg}$, determined based on their chemical compositions [87]. $\mathrm{CO}_{2}$ also could be mineralized in several hours with magnesium-bearing compounds through the formation of $\mathrm{MgCO}_{3}$ under typical conditions of $\mathrm{CO}_{2}$ partial pressure $>10 \mathrm{MPa}$, and temperature $>417.15 \mathrm{~K}[88,89]$. Though the total amount of manmade alkaline solid residues is limited compared to natural ores/minerals, scale-up demonstrations should reduce some of the technical barriers to processing natural minerals for $\mathrm{CO}_{2}$ mineralization and utilization.

Compared to natural minerals, industrial solid residues are more reactive and usually available in a finely ground state, reducing or eliminating the need for additional pretreatment. The lack of reactivity of serpentine rock and similar minerals has been a major problem for mineralization of natural rocks and may demand grinding down to micron size and reaction in salt solutions at pressures up to $10 \mathrm{MPa}$ or more, since in nature, reactions with $\mathrm{CO}_{2}$ are exceedingly slow $[90,91]$. Fig. 6 shows the mechanisms and important reaction routes of $\mathrm{CO}_{2}$ mineralization with brucite, in the case of using mine tailings. The mechanisms of $\mathrm{CO}_{2}$ mineralization using alkaline residue slurry can be described by three main steps: (i) dissolution of gaseous $\mathrm{CO}_{2}$ into the aqueous phase; (ii) dissolution of minerals; and (iii) precipitation of carbonates. To reduce the fresh water consumption as well as to enhance the mineralization performance, industrial wastewater [92] or concentrated brine [93] can be utilized for $\mathrm{CO}_{2}$ mineralization using alkaline solid 
residues. In addition, the use of brine solution for $\mathrm{CO}_{2}$ mineralization may enhance the dissolution of calcium- and magnesium-bearing silicate minerals [94]. Due to the chemical and mineralogical complexity of alkaline residues, further elucidation of reaction pathways and mechanisms at the interface of liquid-solid phases is needed to understand and improve the kinetics and mass transfer in the $\mathrm{CO}_{2}$ mineralization processes.

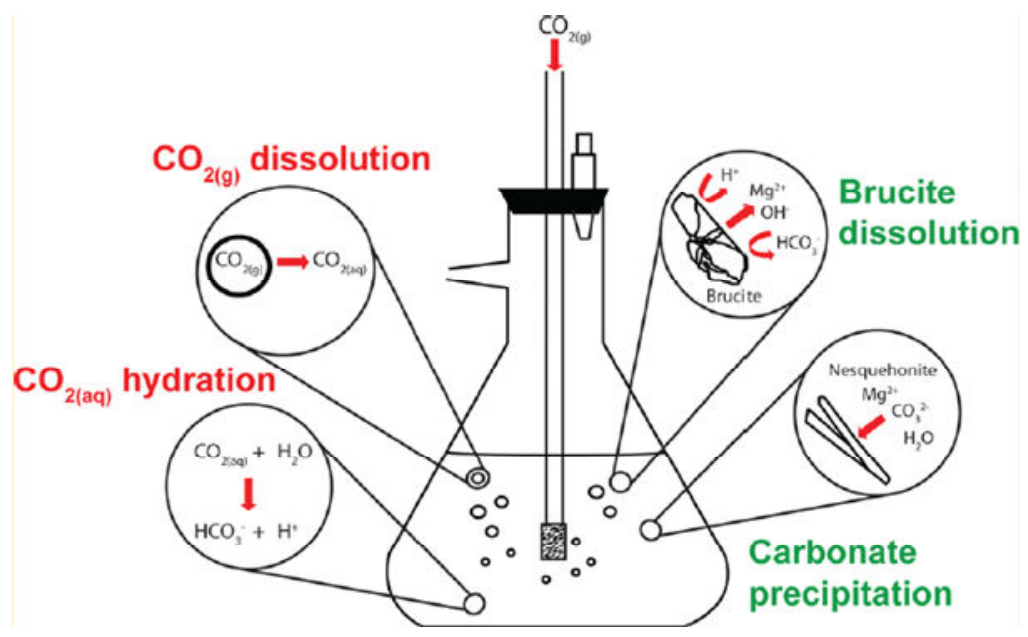

Fig. 6 Mechanisms and important reaction routes of $\mathrm{CO}_{2}$ mineralization using alkaline residues, e.g., brucite including $\mathrm{Mg}(\mathrm{OH})_{2}$ in mine tailings. Reprinted with permission from Ref. [81].

$\mathrm{CO}_{2}$ mineralization using alkaline solid residues can also be beneficial for air pollution control for various industries and/or coal-fired power plants (as depicted in Fig. 7). For instance, Pei et al. [71] evaluated the performance of high-gravity mineralization technologies using fly ash for the removal of air pollutants from the petrochemical industry. The results showed that the removal efficiencies for $\mathrm{CO}_{2}, \mathrm{NO}_{\mathrm{x}}$ and particulate matter were approximately $96 \%, 99 \%$ and $83 \%$, respectively. The reacted solid residues can be used in construction as alternative cementitious materials in concrete or cement mortars [67]. The products from $\mathrm{CO}_{2}$ mineralization should be engineered toward diverse applications in the built environment. For other mineralization approaches, the products from indirect carbonation also can be converted to high-value-added materials, such as geopolymers, abiotic catalysts, soil conditioners, glass ceramics and calcium carbonate precipitate. 
Similarly, the electrochemical mineralization technologies can sequester gaseous $\mathrm{CO}_{2}$ from various industries while generating electrical energy and $\mathrm{NaHCO}_{3}$ product [95].

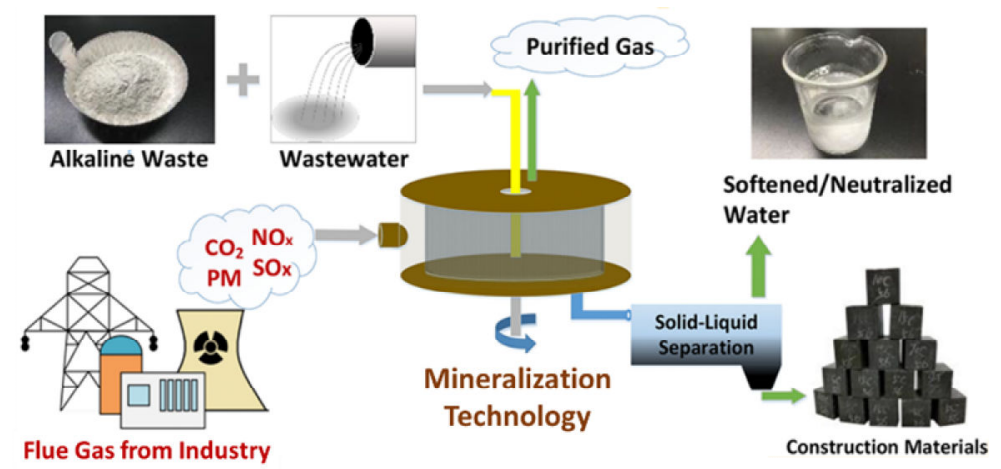

Fig. $7 \mathrm{CO}_{2}$ mineralization using alkaline residues with integrated air pollution control from industries and power plants. Adapted from Ref. [71].

Although the amount of $\mathrm{CO}_{2}$ that can be mineralized is limited in comparison to the total global $\mathrm{CO}_{2}$ emissions, it offers the added benefits of remediating alkaline solid residues, as well as of generating marketable products from the solid residues. However, significant technological breakthroughs are required before deployment in a cost-effective manner can be realized. This includes novel reactor design, process intensification, heat integration and system optimization. The hybridization of $\mathrm{CO}_{2}$ mineralization with other concepts or processes, such as integrated air pollution control or water reclamation, should be a future priority research direction. Also, several unit processes used in $\mathrm{CO}_{2}$ mineralization, such as feedstock grinding, process heating and slurry stirring, consume a substantial amount of energy. Therefore, energy consumption of $\mathrm{CO}_{2}$ mineralization needs to be compensated by recovering energy from the exothermic reactions to make the process economically viable in an industrial context [96-98]. To achieve a waste-to-resource supply chain, a system optimization from the energy, engineering, environmental, and economic sectors is also required [99].

\subsection{Beverage and Food Processing}

In the beverage and food industry, $\mathrm{CO}_{2}$ can be utilized as an acidifying agent [100]. 
However, $\mathrm{CO}_{2}$ purity is a very significant factor due to possible contamination of the final products from benzene, $\mathrm{COS}$, and $\mathrm{H}_{2} \mathrm{~S}$ from gasification processes and $\mathrm{SO}_{2}$ and $\mathrm{NOx}$ from combustion sources. Currently, the main uses of food-grade carbon dioxide are in producing carbonated drinks, de-oxygenated water, milk products, and food preservation. Beer, soft drinks, and sparkling wine consume large quantities of liquid $\mathrm{CO}_{2}$ for their production and, therefore, it is important that the $\mathrm{CO}_{2}$ used comes from renewable sources or recycled $\mathrm{CO}_{2}$. In conventional food preservation, mechanical refrigeration is mainly used during transportation and storage. However, for foods that require freeze drying (dehydration), liquid carbon dioxide, dry ice (i.e., the solid form of $\mathrm{CO}_{2}$ ) and modified atmosphere packaging (MAP) technologies are more widely used for refrigeration. The major limitation of such approaches is that "storage" is transitory, and the best justification of such technologies is if the source of $\mathrm{CO}_{2}$ replaced represents "new potential off-set" $\mathrm{CO}_{2}$ being released to the atmosphere, in which case careful life cycle analysis is needed to estimate the benefit of replacing $\mathrm{CO}_{2}$ production from fossil fuels such as methane [101].

Supercritical fluid extraction (SFE) technology is an approach for utilizing $\mathrm{CO}_{2}$ in the production of flavors and essential oils, and coffee decaffeination, which is beneficial to the separation and extraction of heat-sensitive, volatile and oxidizable components. In comparison with the traditional separation methods, it has the following advantages [102104]: The extraction agent in SFE is typically non-toxic, non-corrosive, and chemically stable; SFE provides better permeability than other solvent techniques; The extraction capability of SFE can be controlled easily by adjusting the main operating parameters; and the extraction agent can be reused after decompression to save energy.

Thus, supercritical $\mathrm{CO}_{2}$ extraction (SCE) technology is preferred in food manufacturing owing to the above merits. In 1978, SFE technology was first industrially employed in Germany for extracting caffeine from coffee beans [105]. Currently, this 
technology has been extensively applied in daily life as illustrated in Fig. 8 [106]. Important applications of SFE technology include the extraction of oils and fat fractions [107-111], lipids and cholesterol [112, 113], natural colors [114], antioxidants [115, 116], and hops [117, 118], and decaffeination of tea and coffee [119-121].

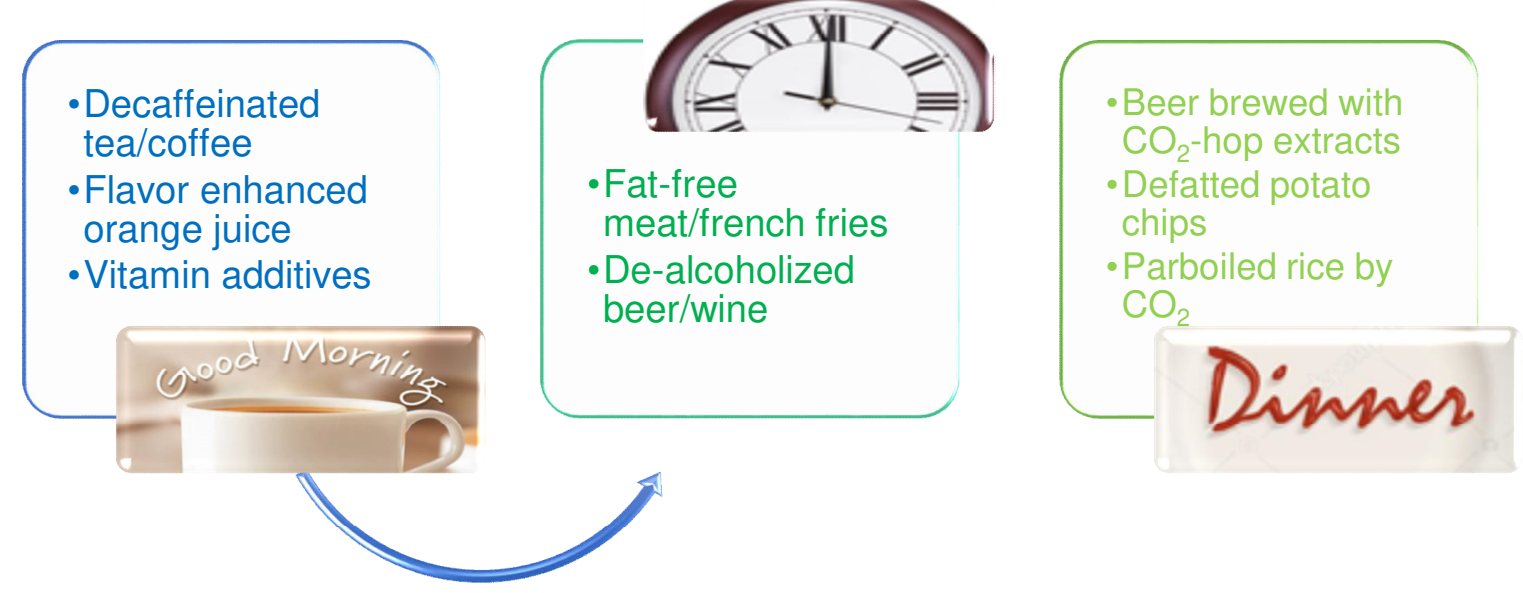

Fig. 8 Representative daily food obtained by supercritical fluid extraction. Reprinted with permission from Ref. [106].

A number of essential oils (EOs) are widely used in foods or cosmetics. Table S1 shows the extraction yields of EOs from various samples at the optimum operating conditions, i.e., temperature, pressure, and extraction time reported in the recent literature. Importantly, SCE is found to exhibit better extraction performance than some other extraction technologies. Conde-Hernández et al. [122] claimed that $\mathrm{CO}_{2}$-supercritical extraction has higher antioxidant activity and oil yield, compared with steam distillation (SD) and hydrodistillation (HYDRO) methods. Micrographs of rosemary before and after SCE treatments are shown in Fig. 9, which provides a vivid description of the changes in the samples. The surface of the rosemary was smooth before treatment (Fig. 
9(a)); however, the samples tended to collapse after exposure to the supercritical extraction under different temperatures and pressures (Fig. 9(b) and 9(c)). Moreover, watermelon seed oil was extracted via SCE technology by Rai et al. [123]. As depicted in Fig. 9(d) and 9(e), the surface of the extracted seed layers was cracked and both oil and non-extracted phase were closely interpenetrating after the extraction compared to a rough surface before the extraction. The response surface methodology (RSM) was used to optimize the operating condition parameters including pressure, temperature, particle size, solvent flow rate, and co-solvent addition and obtain the maximum oil yields as shown in Fig. 9(f). More recently, the SFE techniques assisted by other methods such as enzymes [124, 125], ultrasound [126, 127], and microwave [128-130], have been extensively reported. However, development of SCE technology must meet various hurdles due to the need for sophisticated equipment, difficulties in continuous production, and relatively high costs of the pilot-scale equipment, which slow the development of this technology.

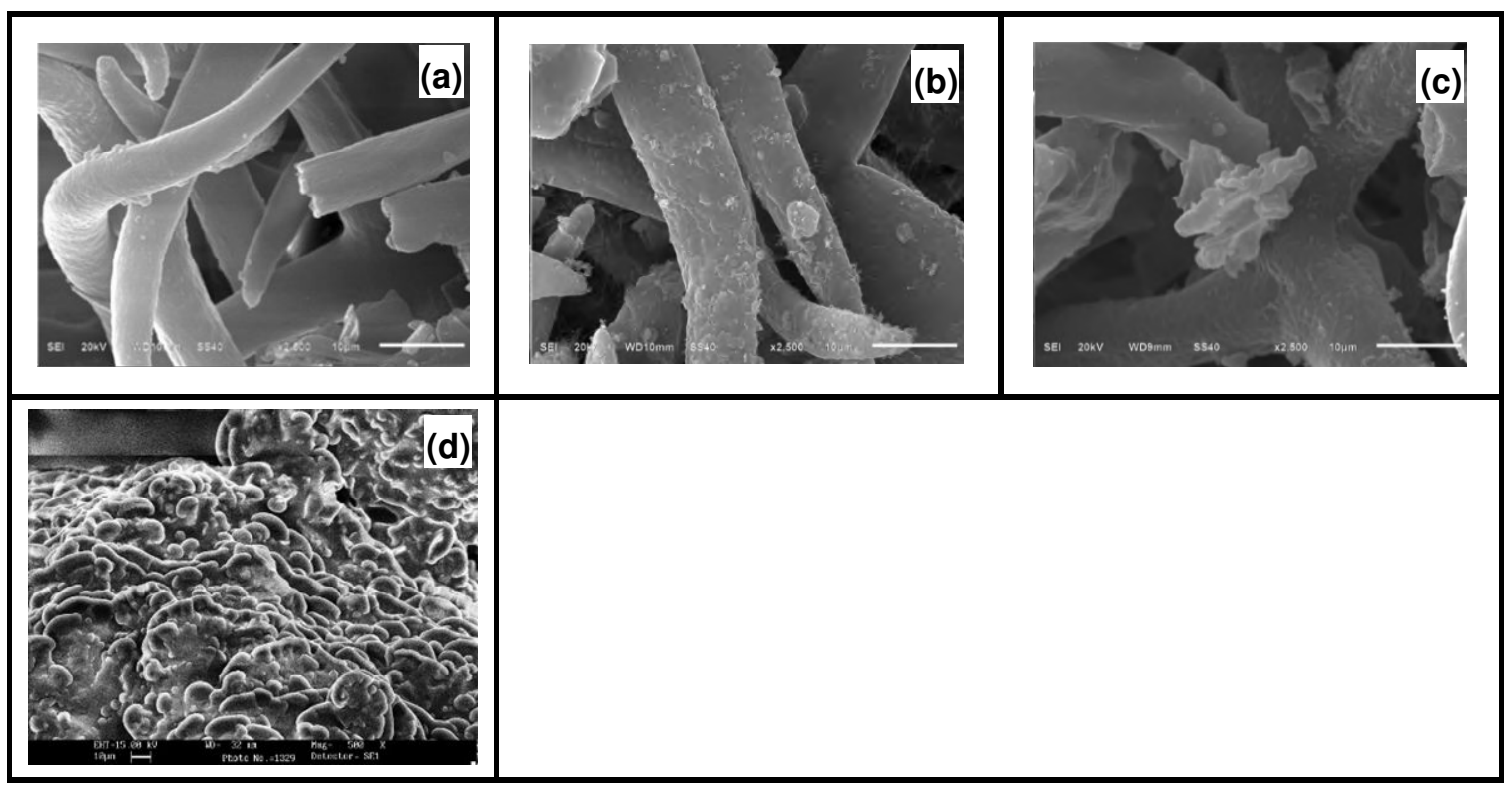




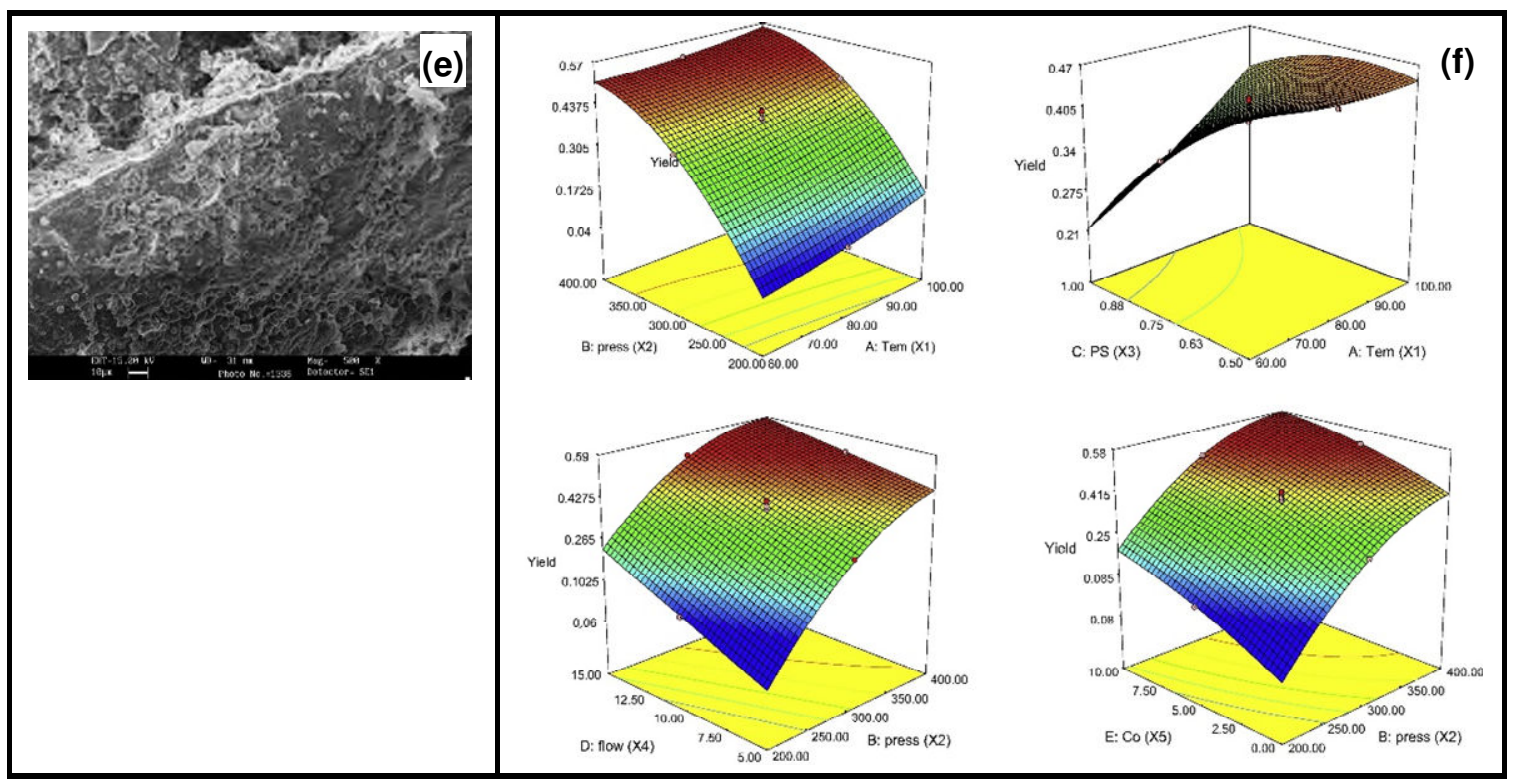

Fig. 9 Scanning electron microscopy (SEM) images of rosemary (a) before SCE treatment, and after SCE treatment (b) at 10.34 MPa and $323 \mathrm{~K}$, and (c) at 17.24 MPa and $313 \mathrm{~K}$. Watermelon seed (d) before SCE treatment, and (e) after SCE treatment, (f) maximum oil yields with different condition combinations. Reprinted with permission from Refs. [122, 123].

\subsection{Biological Utilization}

In nature, $\mathrm{CO}_{2}$ is converted to carbohydrates through photosynthesis, as part of the natural carbon cycle. The biological fixation of $\mathrm{CO}_{2}$ is a safe and cost-effective method using plants and autotrophic microorganisms. In particular, autotrophic microorganisms are advantageous because of their small volume, high photosynthetic rate, strong environmental adaptability, rapid reproduction, high processing efficiency, and easy integration with other technologies. It has been noted that $1 \mathrm{~kg}$ algal biomass can fix about $1.83 \mathrm{~kg} \mathrm{CO} 2$ [131]. Thus, research on microalgae has attracted great attention globally, especially as it could be used as an alternate energy source displacing fossil fuels [132, $133]$.

The carbon sources obtained for microalgae are mainly from the inorganic carbon dissolved in water. During the photosynthesis process of microalgae, $\mathrm{CO}_{2}$ is first fixed by 
ribulose bisphosphate carboxylase-oxygenase (Rubisco), and then converted to organic compounds using light energy through the Calvin-Benson cycle $\left(\mathrm{C}_{3}\right.$ cycle $)$. Since the Rubisco carboxylase reaction is inhibited by high $\mathrm{O}_{2}$ concentrations, the photosynthetic organisms have developed special mechanisms to adapt to variations in the gas composition. In particular, the carbon concentrating mechanism (CCM) is a typical process as shown in Fig. 10 [134]. In a recent study, up-to-date developments in worldwide CCM research and the molecular components' effect on CCM enhancing carbon biofixation were discussed by Singh et al. [135]. The CCM system needs to be further studied to identify the most effective algae species.

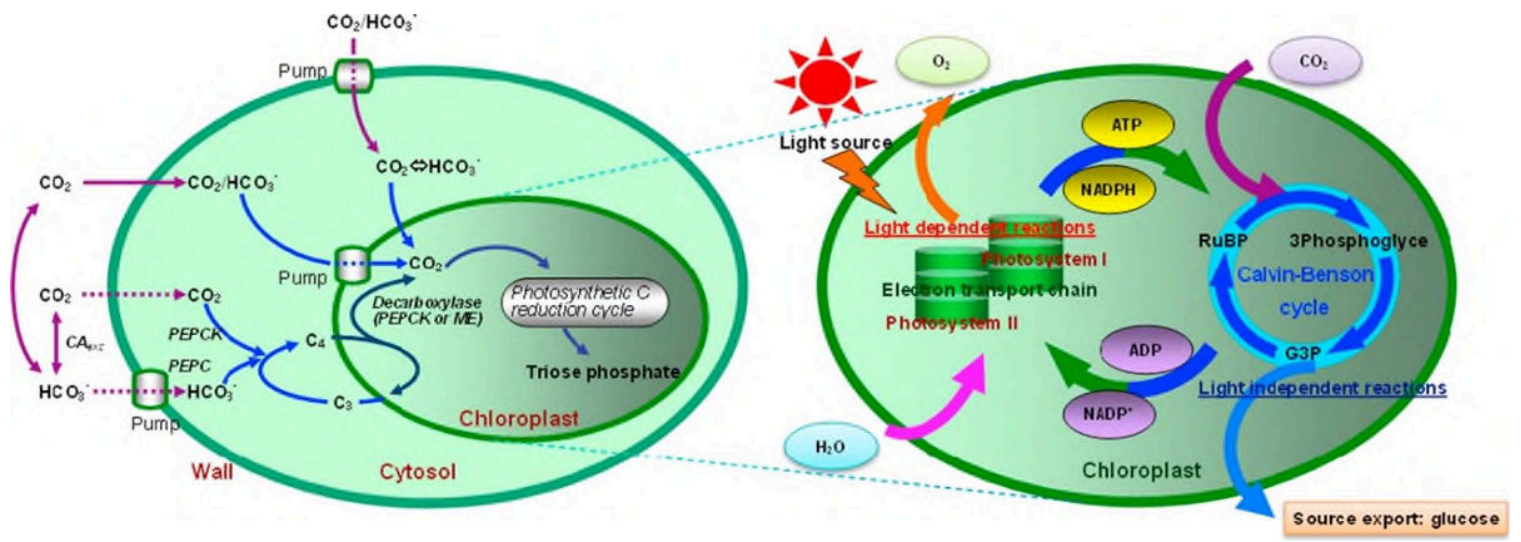

Fig. 10 Schematic of carbon concentrating mechanism process. Reprinted with permission from Ref. [134].

The selection of microalgae type is closely related to the desired application. For $\mathrm{CO}_{2}$ from flue gas, the microalgae not only need a highly-efficient $\mathrm{CO}_{2}$ fixation ability, but also the ability to survive high temperature, high $\mathrm{CO}_{2}$ concentration (10-20\%), and the presence of other gases such as $\mathrm{NO}_{\mathrm{x}}$ and $\mathrm{SO}_{\mathrm{x}}$. For trace $\mathrm{CO}_{2}$ (below $0.1 \%$ ) in an enclosed reaction apparatus, it should have a wide range of $\mathrm{pH}$, and high $\mathrm{CO}_{2}$ conversion rate $[136,137]$. Table 1 lists the common use of different microalgae for $\mathrm{CO}_{2}$ fixation. 
Table $1 \mathrm{CO}_{2}$ fixation performance using different algae.

\begin{tabular}{|c|c|c|c|c|}
\hline Algae & $\begin{array}{l}\text { Temperature, } \\
\text { K }\end{array}$ & $\begin{array}{l}\mathrm{CO}_{2} \text { level, } \\
\text { vol\% }\end{array}$ & $\begin{array}{l}\text { Maximum } \mathrm{CO}_{2} \text { fixation } \\
\text { rate, } \mathrm{g} /(\mathrm{L} \cdot \mathrm{d})\end{array}$ & Ref. \\
\hline Anabaena sp. & 308 & 10 & 1.010 & [138] \\
\hline $\begin{array}{l}\text { Botryococcus } \\
\text { braunii }\end{array}$ & 298 & 5 & 0.497 & [139] \\
\hline Botryococcus sp. & 303 & 10 & 0.257 & {$[140]$} \\
\hline $\begin{array}{l}\text { Chlorella } \\
\text { pyrenoidosa }\end{array}$ & 298 & 10 & 0.260 & {$[141]$} \\
\hline $\begin{array}{l}\text { Chlorella } \\
\text { sorokiniana }\end{array}$ & 298 & 4.1 & 0.251 & {$[142]$} \\
\hline \multirow{4}{*}{ Chlorella sp. } & 303 & 10 & 0.252 & {$[140]$} \\
\hline & 293 & 5 & 0.700 & [143] \\
\hline & 298 & 5 & 0.252 & {$[139]$} \\
\hline & 298 & 0.093 & 3.552 & {$[144]$} \\
\hline \multirow[t]{3}{*}{ Chlorella vulgaris } & 303 & 1 & 6.240 & {$[145]$} \\
\hline & 298 & 5 & 0.162 & {$[146]$} \\
\hline & 298 & 2 & 0.430 & {$[147]$} \\
\hline $\begin{array}{l}\text { Dunaliella } \\
\text { tertiolecta }\end{array}$ & 298 & 5 & 0.272 & [139] \\
\hline Euglena gracilis & 300 & 10 & 0.074 & {$[148]$} \\
\hline $\begin{array}{l}\text { Nannochloropsis } \\
\text { sp. }\end{array}$ & 303 & 10 & 0.265 & {$[140]$} \\
\hline & 303 & 12 & 0.140 & [149] \\
\hline Scenedesmus & 301 & 10 & 0.549 & {$[150]$} \\
\hline \multirow[t]{2}{*}{ obliquus } & 301 & 20 & 0.390 & {$[151]$} \\
\hline & 298 & 10 & 0.288 & [141] \\
\hline
\end{tabular}




\begin{tabular}{lllll}
\hline Scenedesmus sp. & 298 & 2.5 & 0.368 & {$[152]$} \\
& 303 & 10 & 0.210 & {$[140]$} \\
Spirulina platensis & 298 & 5 & 0.319 & {$[139]$} \\
Spirulina sp. & 303 & 6 & 0.220 & {$[149]$} \\
\hline
\end{tabular}

Physiochemical parameters during the fixation process, such as culture temperature, $\mathrm{CO}_{2}$ concentration, light, and $\mathrm{pH}$ value, have an impact on the biofixation of $\mathrm{CO}_{2}[153]$ :

(1) Culture temperature is an important factor for the photosynthesis efficiency of microalgal-carbon biofixation. Generally, microalgae also have an optimum growth temperature range of 291 to $298 \mathrm{~K}$. Extremely high or low temperatures slow down the microalgal growth, by reducing the activity of Rubisco, which is the key plant enzyme for $\mathrm{CO}_{2}$ fixation [101].

(2) In the past decades, the photobioreactor (PBR) or enclosed cultivation system was widely used. Light (sunlight or artificial light) plays a significant role in microalgae growth, reactor design and system operation, providing the energy for assimilation and activating some enzymes involved in the photosynthesis. However, long-time exposure can easily cause aging of the equipment, and the operation of the equipment may be affected by heat generation from the illumination [134].

(3) The $\mathrm{pH}$ can easily reach a high value of 10 under the conditions of high-density cultivation and without the supplement of $\mathrm{CO}_{2}$. In addition, a high-pH environment seriously affects the photosynthetic reaction process and cell uptake of nutrient salts, which leads to a decrease of microalgae biomass yield. Therefore, during the cultivation of the algae, the $\mathrm{pH}$ should be stabilized and managed to be neutral $(\mathrm{pH}=6-8)$ [154].

(4) $\mathrm{CO}_{2}$ concentration has an impact on the growth of the microalgae, and in general, a suitable value is $10-20 \%$ [155]. It is possible to use fossil fuel flue gas or the gas emissions from the steel and cement industries directly. Also, some types of microalgae show good 
growth performance at higher $\mathrm{CO}_{2}$ concentrations. For example, Chlorococcum littorale has a better growth performance when $\mathrm{CO}_{2}$ concentration is higher than $40 \%[156,157]$. Synechocystis aquatilis has also been proved to grow with a $\mathrm{CO}_{2}$ concentration of $40 \%$ [158]. These studies could help to improve microalgae tolerance using high concentrations of $\mathrm{CO}_{2}$ from fossil fuel combustion flue gas. More research is also being devoted to genetically modifying algae to improve their ability to capture $\mathrm{CO}_{2}[159]$.

\subsection{Enhanced Oil Recovery, Coal Bed Methane and $\mathrm{CO}_{2}$ Fracking}

Geologic $\mathrm{CO}_{2}$ storage involves injecting captured $\mathrm{CO}_{2}$ into underground reservoirs with suitable geological conditions, where $\mathrm{CO}_{2}$ can be securely stored underground for more than 10,000 years [160]. However, it is possible to inject $\mathrm{CO}_{2}$ into oil and gas reservoirs to enhance the production of fossil fuels [161]. $\mathrm{CO}_{2}$ could be injected into depleted oil reservoirs, shale formations and unmineable coal seams for tertiary recovery or enhanced oil recovery (EOR), enhanced shale gas recovery (ESGR) and enhanced coalbed methane (ECBM) recovery, respectively. A future possible use of $\mathrm{CO}_{2}$ is utilization as a fracturing fluid, thus eliminating or reducing the use of water [162].

The EOR method refers to extracting crude oil from oilfields, which could not be extracted by primary and secondary recovery. Three main techniques for EOR are chemical injection (e.g., polymer flooding and surfactant-polymer injection), thermal injection (e.g., in situ combustion, steam flood, and steam stimulation), and gas injection (e.g., natural gas, $\mathrm{CO}_{2}$, and $\mathrm{N}_{2}$ ) [163-165]. Among these, since the $1970 \mathrm{sO}_{2}$ has been most commonly utilized for miscible displacement (Fig. 11), due to decreasing oil viscosity and a cheaper cost than liquefied petroleum gas (LPG). Stewart et al. claimed that there can be net emissions of $\mathrm{CO}_{2}$ when the maximum utilization of $\mathrm{CO}_{2}\left(\mathrm{CO}_{2} \mathrm{EOR}+\right)$ process could store more carbon than produced [166]. $\mathrm{CO}_{2}$-EOR projects in operation are mainly in the US and Canada, which are also associated with available sources of $\mathrm{CO}_{2}$. The number of projects is growing in other regions such as China and Australia since $\mathrm{CO}_{2}$-EOR is treated 
as an early CCUS adoption $[167,168]$. Higher than $90 \%$ of the oil reservoirs worldwide might be suitable for using $\mathrm{CO}_{2}$-EOR technology [169]. Four important factors should be considered for further expanding $\mathrm{CO}_{2}$-EOR technology including the monitoring of underground and vented emissions, strengthening the risk management to the site capacity, and improving the utilization of the abandoned fields.

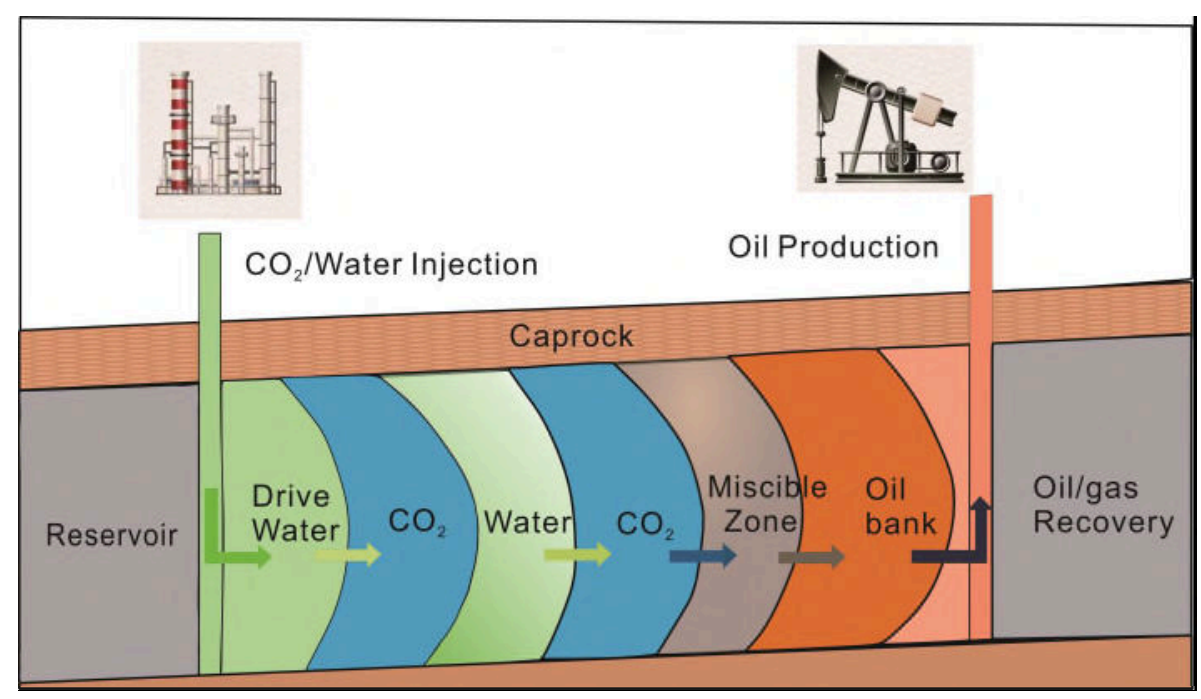

Fig. 11 Schematic of $\mathrm{CO}_{2}$-EOR process.

Shale gas has become an important alternative to natural gas (i.e., unconventional natural gas) over the past decade. $\mathrm{CO}_{2}$ injection to enhance shale gas recovery in gas reservoirs is also an effective technique to improve the gas yield $[170,171] . \mathrm{CO}_{2}$ is also potentially more soluble than $\mathrm{CH}_{4}$ in geological formations, and can replace desorbed $\mathrm{CH}_{4}$ in pores and fractures, thereby increasing the recovery rate as depicted in Fig. 12 [172]. To date, a large number of experimental and theoretical studies have been carried out on ESGR considering different influence factors such as reservoir and gas injection pressures [173175], injection and production time [176-178], and physical characteristics of the reservoir $[179,180]$. This method is also proven to be a feasible means of natural gas recovery [181]. Injecting $\mathrm{CO}_{2}$ into gas hydrates to extract natural gas has attracted increasing interest [67, 182]. As a result, future research will likely be carried out to help commercialize this technology, in order to provide a route to long-term storage of $\mathrm{CO}_{2}$. 


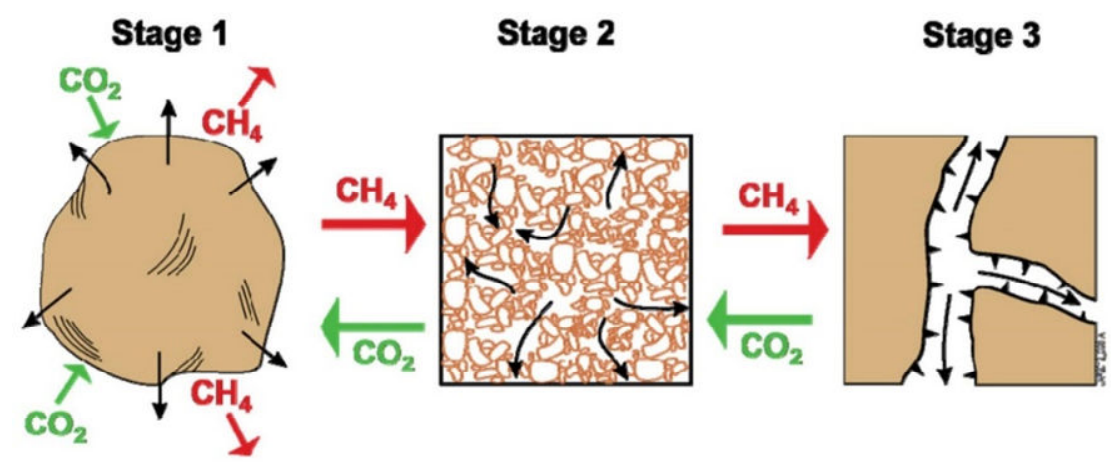

Fig. $12 \mathrm{CH}_{4}$ and $\mathrm{CO}_{2}$ flow dynamics in gas shales. Reprinted with permission from Ref. [172].

Moreover, $\mathrm{CO}_{2}$ can be injected into deep coal seams (i.e., ECBM), which not only improves coalbed methane recovery, but also sequesters $\mathrm{CO}_{2}$. The mechanisms of $\mathrm{CO}_{2}$ ECBM are presented in Fig. 13. A number of modeling, lab-scale studies, and small-scale field $\mathrm{CO}_{2}$-ECBM tests have been conducted. For example, Sun et al. [183] simulated the distributions of gas pressure and gas sorption performance during $\mathrm{CO}_{2}-\mathrm{ECBM}$ (Fig. 13). They noted that gases were mainly absorbed in the pores, and $\mathrm{CH}_{4}$ diffused from the interior to the exterior of the samples, while $\mathrm{CO}_{2}$ diffused in the opposite direction. However, almost all CBM is currently produced by removing water from the coal seam that decreases the pressure and enables $\mathrm{CH}_{4}$ release from the coal. A detailed understanding of $\mathrm{CO}_{2}$ sorption in reservoir conditions is needed to accelerate the commercial deployment of the technology. 


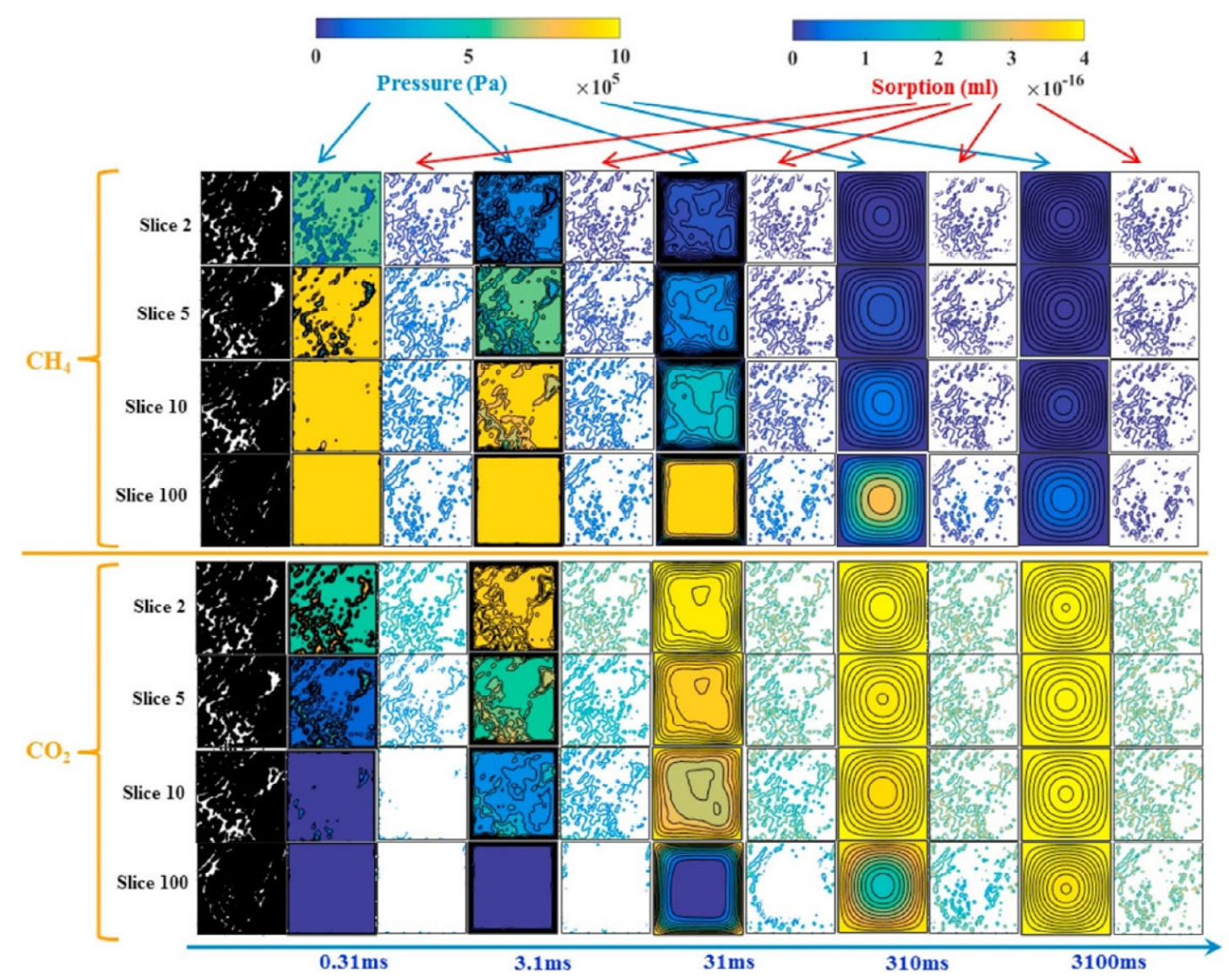

Fig. 13 Gas sorption and its pressure distributions in coal via $\mathrm{CO}_{2}-\mathrm{ECBM}$ technology (at 1 $\mathrm{MPa}$ ). Reprinted with permission from Ref. [183].

\subsection{Leading and Promising Utilization Technologies}

The recovered $\mathrm{CO}_{2}$ has already been stored in oil and gas wells and aquifers, and underground cavities also provide more possibilities. The $\mathrm{CO}_{2}$ injection method for EOR has been employed in several regions. However, there are potential issues such as water supply leakage or acidification, which are still not completely understood, and transportation of supercritical $\mathrm{CO}_{2}$ is also energy-intensive. In order to promote this technology, corrosion and other $\mathrm{CO}_{2}$ transportation pipeline problems should be solved [184].

Ultimately, $\mathrm{CO}_{2}$ conversion methods require different energy inputs, and renewable energy sources such as wind or solar power, which themselves have a minimal carbon 
footprint, are the most obvious energy sources for such processes, where the energy for such processes is not used directly to make electricity, i.e., stranded energy resources. If the prices of renewable energy continue to decrease, it could enable greater utilization of the energy for $\mathrm{CO}_{2}$ conversion via chemical or catalytic approaches. Thus, microalgae can be a solution to produce liquid fuels and achieve $\mathrm{CO}_{2}$ emission reduction. However, to make such methods economically viable, governments will need to intervene in the market. One major advantage of microalgae is the fact that such developments, especially no land use competition, are likely to receive significant public support [185]. Key challenges for such technologies include increasing the lipid content and also its conversion to biofuels with low $\mathrm{CO}_{2}$ emission and energy consumption. It is important also to realize that such technologies will have specific geographic locations for early production or adoption based on local conditions and resources. In the short term, the production of simple industrial chemicals such as urea, methanol, and methane are still the most mature and closer to commercial application and are demanded in large volumes, making them more interesting if the goal is to reduce anthropogenic $\mathrm{CO}_{2}$ emissions. Interestingly, integrated systems using different utilization methods may be a promising solution such as methanol production integrated with enhanced gas recovery (EGR) [186], or methanol and dimethyl ether synthesis [187].

$\mathrm{CO}_{2}$ can be used in a number of ways, leading to different disposal options and making their evaluation difficult to quantify. Before the commercialization of these $\mathrm{CO}_{2}$ utilization methods, the life cycle assessment (LCA) or techno-economic analysis (TEA) is beneficial to help identify promising utilization pathways $[58,188]$. According to the tutorial review by von der Assen et al. ${ }^{[188]}$, LCA is able to identify environmentally promising routes for CDU even in the early development stage. A variety of comprehensive reviews have focused on studying the life cycle environmental effects of different CDU strategies or a specific $\mathrm{CO}_{2}$ utilization approach in detail [189-191], which can provide future insights for suitable $\mathrm{CO}_{2}$ utilization pathways in particular instances. Therefore, the ideal methods 
for $\mathrm{CO}_{2}$ utilization need low additional energy, simpler reaction mechanisms and high future market size and value.

\section{Trends in Global $\mathrm{CO}_{2}$ Utilization Projects}

In this decade, a variety of facilities to utilize $\mathrm{CO}_{2}$ throughout the world have been operated, constructed, or announced, involving different-scale applications. These ongoing $R \& D$ projects are at the various stages of technological readiness but all are located in or are led by technologically advanced countries.

\subsection{United States}

The United States leads the deployment technology of CCS in the world especially the EOR technology. The United States Department of Energy (DOE) has promoted the CCS knowledge base via a wide portfolio of research projects since 1997. Three technologies in the United States for $\mathrm{CO}_{2}$ utilization are focused on boosting the commodity market for $\mathrm{CO}_{2}$, including chemicals, mineralization, and polycarbonate plastics. These methods are expected to be in large-scale testing by 2030 , with widespread commercial applications by 2035. To support the development in the regional infrastructure for CCS, seven Regional Carbon Sequestration Partnership (RCSP) regions have been created since 2003, as shown in Fig. 14 [192]. Approximately \$2.66 billion has been invested by DOE in 794 differentscale R\&D projects since 2010 [193]. Meanwhile, the United States has increased the carbon tax credit to $\$ 35 / t$ for EOR use and $\$ 50 / t$ for storage in saline formations by 2026 , which was initially \$10/t in 2008 [194]. In addition, the United States is collaborating with various global organizations on CDU and CCS projects. 


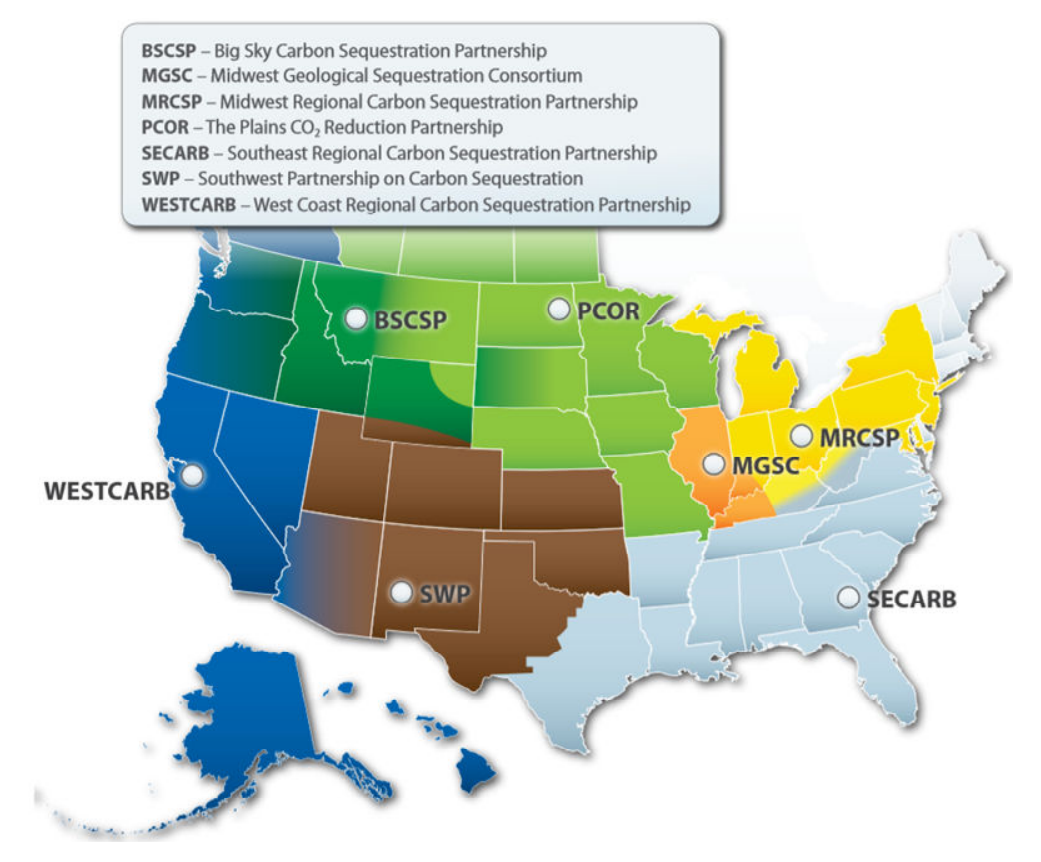

Fig. 14 United States Regional Carbon Sequestration Partnership network [192].

\subsection{China}

In China, R\&D activities on CCS are mainly financially supported by the government and conducted by industrial companies with the joint participation of universities or research institutes. One of the national key scientific and technological projects of "Large Oil and Gas Fields and Coal Seam Gas Development Projects" invested more than $\$ 40$ million to promote demonstration of the $\mathrm{CO}_{2}-\mathrm{ECBM}$ and $\mathrm{CO}_{2}-\mathrm{EOR}$ techniques [195]. In 2018, the first large-scale CCS facility was commenced by China National Petroleum Company [196]. Furthermore, the Chinese government actively participates in the Carbon Sequestration Leadership Forum (CSLF), Clean Energy Ministerial (CEM) conference and some international frameworks, and supports domestic research institutes and companies involved in bilateral and multilateral cooperation projects [195]. Currently China owns the largest number of CCS pilot and demonstration plants in operation, construction, and planning. 


\subsection{United Kingdom}

Since 2017, the United Kingdom government has announced new strategies (e.g., Clean Growth Strategy) to support advancements in carbon capture, usage and storage. Three routes are promoted: development of innovative technology, development of international collaboration on CCUS, and research on reducing costs in CCUS projects. A number of CCUS deployment projects are planned to start in the next two or three decades. The government has invested more than $£ 130$ million on CCUS R\&D and innovation since 2011. In addition, $£ 20$ million has been allocated to design and support CCU demonstration projects for developing innovative techniques [197]. More recently, the government awarded $£ 26$ million to advance $\mathrm{CCS}$, and the largest $\mathrm{CO}_{2}$ capture project to date in the United Kingdom will be able to remove and use 40000 t/y $\mathrm{CO}_{2}$ [198]. Even allowing for the United Kingdom leaving the EU, there will be little effect on the current Energy policy due to its Climate Change Act [198]. This requires that the United Kingdom reduce $\mathrm{CO}_{2}$ emissions by $80 \%$ from 1990 levels by 2050 to meet its $\mathrm{CO}_{2}$ emissions target.

\subsection{Australia}

The Australian government is involved in a variety of international forums that aim to promote the development and deployment of CCS such as CSLF, the Australia-China Joint Coordination Group and others within and beyond the Asia Pacific region. The China Australia Geological Storage (CAGS) projects included: Phase 1 on clean development and climate (from 2009 to mid-2012); Phase 2 on clean coal technology (from mid-2012 to 2015); and Phase 3 on bilateral CCS/CCUS cooperation (from 2016 to 2018) [199].

\subsection{Norway}

Norway has deployed two commercial-scale CCS projects at Sleipner in 1996 and at Snøhvit in 2007 [200]. In 2018, the Norwegian government allocated about $€ 29$ million to promote CCS deployment including the funding for two full-chain CCS projects. Each 
project will capture 400 billion t per annum of $\mathrm{CO}_{2}$ for storage below the North Sea seabed. More recently, the government announced funding of about $€ 36$ million to the CCS exploration well in April 2019 [201].

\subsection{Germany}

Since 2002, the German government has set goals for combatting climate change, i.e., decreasing GHG emissions by 40\% (2020) and 80\% (2050) compared with 1990 levels [202]. In 2015, they renewed the targets as "New High-Tech-Strategy" that defines the major future directions. From 2010 to 2016, 33 CDU projects were granted, through the government, around $€ 100$ million in total, and $€ 50$ million was paid by various industries to support research projects [203]. Furthermore, the German Federal Ministry of Education and Research (BMBF) employed the efficient integrated method considering the scientific and socio-economic competencies in climate services. In order to trigger innovations, Germany supports a wide range of R\&D programs for CDU.

\subsection{Future Directions in R\&D Projects}

Currently, a number of projects for $\mathrm{CO}_{2}-\mathrm{EOR}, \mathrm{CO}_{2}-\mathrm{ECBM}$, and $\mathrm{CO}_{2}$ storage in saline aquifers are ongoing worldwide [204]. Fig. 15 shows the facilities with a scale of 400 t/d or more of $\mathrm{CO}_{2}$ utilization (non-EOR). Approximately $20 \mathrm{CDU}$ projects are being operated or under construction. $\mathrm{CO}_{2}$ could be used in several industrial fields such as mineralization, food and beverage, and algae cultivation, which could promote scaled-up applications of CCS technology [205]. Most of the R\&D projects are centered on the power generation industry, especially coal power generation. However, the great majority of the R\&D projects are still in the early stages, and have not yet reached the pilot-plant scale. Both Petra Nova (United States) and Boundary Dam (Canada), two commercial large-scale electricity-generating plants with CCS, could offset the CCS cost via selling $\mathrm{CO}_{2}$ for EOR [206]. In Europe, the Norwegian CCS projects are successful due to the high national 
carbon taxation and two offshore storage projects, i.e., Port of Rotterdam CCUS project and Norway full-chain CCS, will be expanded in future [207]. It indicates that increasing the carbon tax credits could incentivize more investments in large-scale CCS deployment and boost the confidence in the private sector. In the future, $R \& D$ projects should be concentrated on finding pathways to process intensification of $\mathrm{CO}_{2}$ utilization, taking capture cost and policy support into account. Unfortunately, the development of such R\&D projects is challenging due to their complexity and financial barriers [208]. 


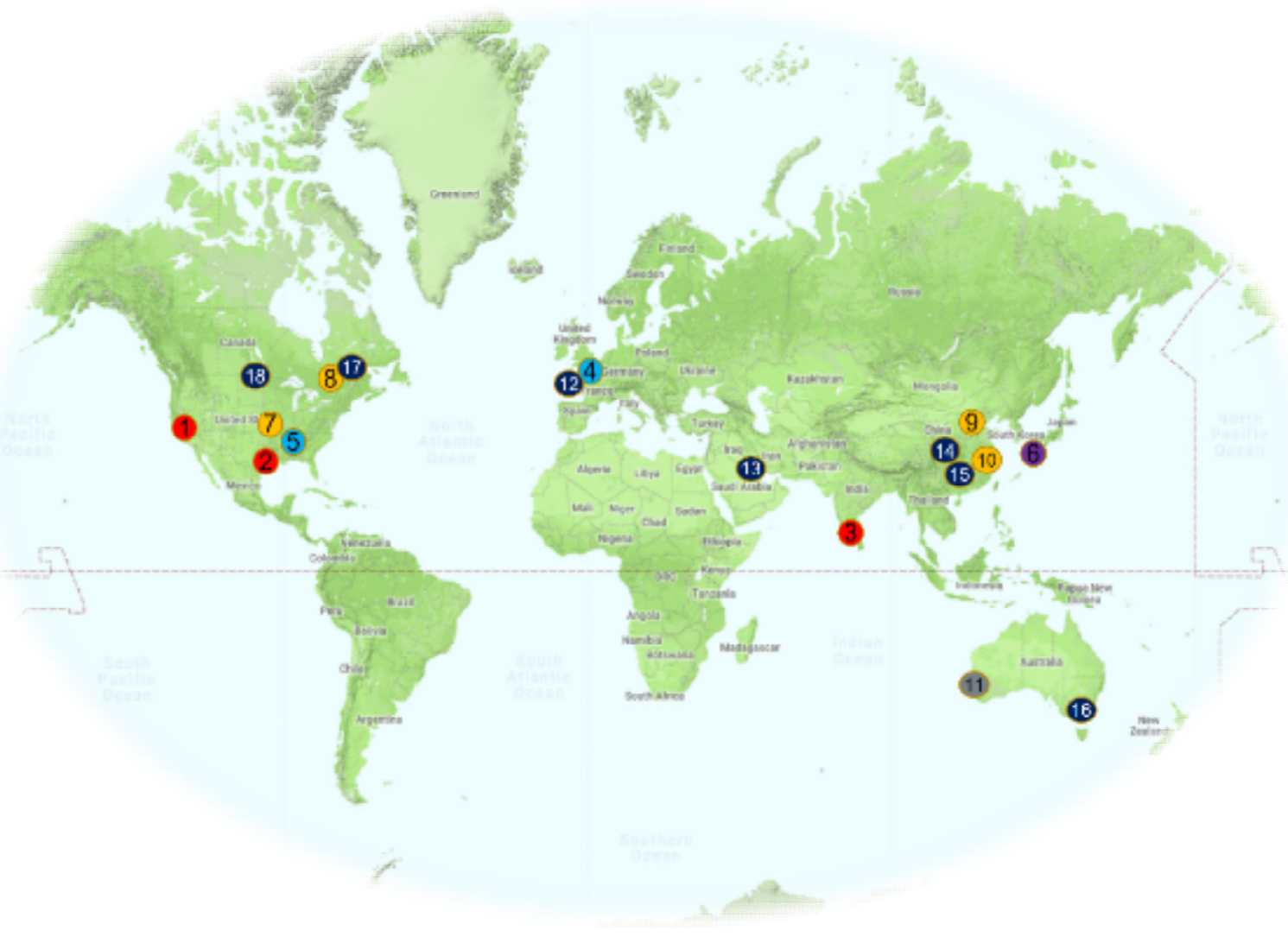

Mineral Carbonation

1. 琶 Searles Valley Minerals $\mathrm{CO}_{2}$ Capture Plant

2. 琶 Skyonic Carbon Capture and Mineralization Project

3. Tuticorin CDU Project

To Be Confirm

4. Port Jérôme $\mathrm{CO}_{2}$ Capture Plant

5. 需 Supercritical $\mathrm{CO}_{2}$ Pilot Plant Test Facility

Algae Cultivation

6. Saga City Waste Incineration Plant

Food and Beverage

7. 彗 AES Shady Point \& Warrior Run $\mathrm{CO}_{2}$ Recovery Plants

8. I Saint-Felicien Pulp Mill and Greenhouse Carbon Capture Project

9. Huaneng Gaobeidian Power Plant Carbon Capture Pilot Project

10. Shanghai Shidongkou $2^{\text {nd }}$ Power Plant Carbon Capture Demonstration

Project

Residue Carbonation

11. Alcoa Kwinana Carbonation Plant

Various Utilization

12. $\mathrm{CO}_{2}$ Utilization Plants - Europe

13. $=$ SABIC Carbon Capture and Utilization Project

14. Chongqing Hechuan Shuanghuai Power Plant Carbon Capture Industrial Demonstration Project

15. $\mathrm{CO}_{2}$ Recovery Plants

16. $\mathrm{CO}_{2}$ Utilization Plants - Oceania Region

17. IN The Valorisation Carbone Québec (VCQ) Project

18. $\mathrm{CO}_{2}$ Utilization Plants - North America

19. $\mathrm{CO}_{2}$ Utilization Plants by the Fluor Econamine FG Process (multiple locations)

20. $\mathrm{CO}_{2}$ Utilization Plants by the KM CDR Process ${ }^{\circledR}$ (multiple locations)

Fig. 15 Distribution of large-scale $\mathrm{CO}_{2}$ utilization projects around the world. 


\section{What is the Potential $\mathrm{CO}_{2}$ Market?}

\subsection{Market Scale and Value}

The size of the individual $\mathrm{CO}_{2}$ utilization markets varies from country to country, which could affect the climate benefit from the CDU approaches. The demand for products using $\mathrm{CO}_{2}$ is increasing gradually. As illustrated in a recent report [209], the $\mathrm{CO}_{2}$ market throughout the world will exhibit an annual growth rate of more than $13 \%$ by 2022 . Fig. 16 displays the potential $\mathrm{CO}_{2}$ utilization in 2050 compared to global $\mathrm{CO}_{2}$ emissions, indicating the enormous markets for $\mathrm{CO}_{2}$ use [210, 211]. However, the $\mathrm{CO}_{2}$ utilization potential is relatively small compared to the $37.1 \mathrm{Gt} / \mathrm{a}$ global $\mathrm{CO}_{2}$ emissions (2018), but could offer the potential of using up to, say, $10 \%$ of anthropogenic $\mathrm{CO}_{2}$ for the production of products like methanol [212]. Use of $\mathrm{CO}_{2}$ is not a substitute for storage due to the large amounts of $\mathrm{CO}_{2}$ needed to be stored. Oil and gas industries are the main contributors to the $\mathrm{CO}_{2}$ market for EOR. For instance, the billions of tonnes of CDU potential in the cement and aggregates industries represent low-margin, highly standardized markets that are difficult to penetrate with new products. As shown in Fig. 17, significant unit price and high market volume of products cannot be obtained simultaneously. It is recommended that the focus should be on four categories of $\mathrm{CO}_{2}$ utilization markets: building materials (such as carbonate aggregates and concrete); chemical intermediates (such as formic acid, methanol, and syngas); fuels (such as methane and liquid fuels); and polymers. For instance, the current market size of methane is 3-4 trillion cubic meters per year (Mt/y), estimated to be $4-5$ trillion cubic meters annually by 2030 . Urea exhibits a market size of $180 \mathrm{Mt} / \mathrm{y}$ with a cheap unit price. The main barriers are low-cost catalysts and the integrated processes of carbon capture and conversion and renewable energy [213]. However, the high cost of these technologies still hampers the growth of the market. Some of the technologies are still at an early development stage, thus the cost/performance should be considered. The methods for utilizing $\mathrm{CO}_{2}$ need further scale-up by improving the market size and 
manufacturing capacity in pilot to commercial plants.

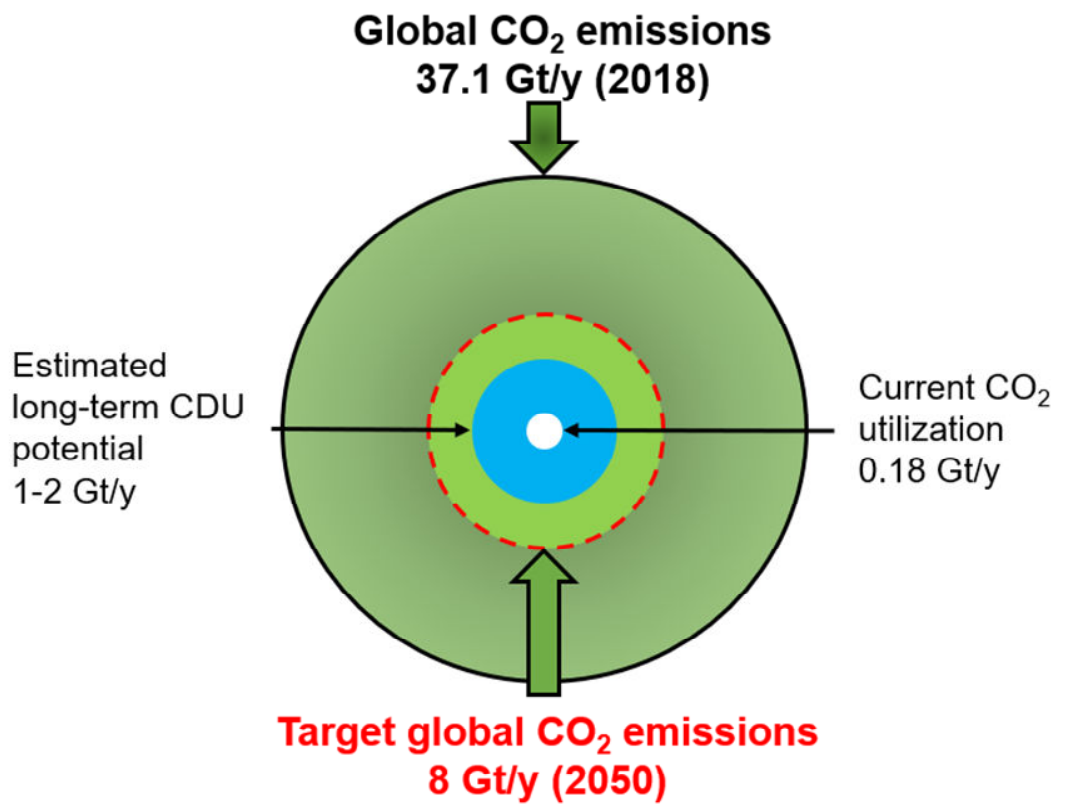

Fig. 16 Comparison between $\mathrm{CO}_{2}$ emissions and utilization potentials.

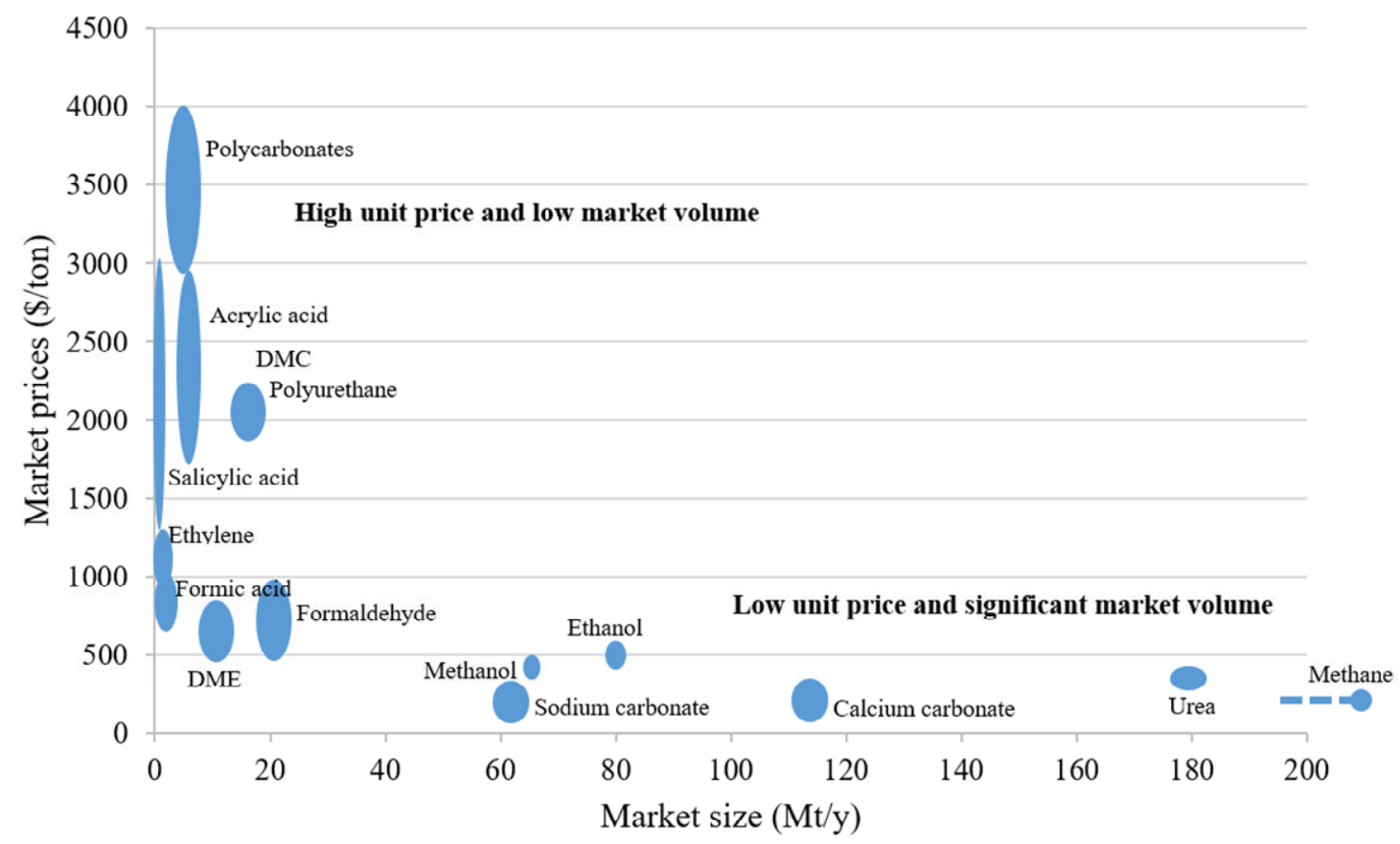

Fig. $17 \mathrm{CO}_{2}$ utilization market potential and value comparisons. Reprinted with permission from Ref. [214]. 


\subsection{Regulation and Policy}

The possibility of failure still exists in the present CCS market. Thus, without a welldesigned policy, the private sector will not invest in CCS at the scale necessary to achieve climate change mitigation targets. A stable regulatory framework is needed to help companies reduce and avoid the negative impacts of failure and increase the financial return from the investment. Therefore, well-designed policies for $\mathrm{CO}_{2}$ utilization are very important to start and build markets. Currently, the range of government policies supporting the deployment of CCS is wide, including carbon pricing, taxes, reporting requirements, government procurement, market mandates (e.g., a low- or zero-emissions portfolio standard) and shareholder actions. In many cases, the products need to meet current standards to be accepted in the marketplace. These standards are normally supervised by the government and industry members, and developed by consensus-based and voluntary committees. Currently, there are few incentives to update or revise the present criteria. Even where the willingness exists, changes to regulatory frameworks are slow and are certainly lagging demand for $\mathrm{CO}_{2}$ reduction [5].

Currently, planning and investment decisions are hampered by a lack of information, the dynamic nature of the technology and the markets, and the changing policy landscape. In general, individual attitudes to accept $\mathrm{CO}_{2}$ utilization technologies and products are positive due to the perceived goal of reduction in $\mathrm{CO}_{2}$ emissions. It is important that the public receives adequate information provided by governments to increase their interest and confidence. Governments should engage early with standards-setting organizations to avoid delays in market entry of these products and expand an innovative agenda for $\mathrm{CO}_{2}$ utilization. Currently, there are only a few countries with specific policy measures to support the deployment of CCS including Norway, the UK, the US, China, Canada, and Japan [215]. In the long term, the government policies are central to increasing the deployment of these technologies and without these drivers $\mathrm{CO}_{2}$ use cannot make a 
significant contribution to meet climate goals. The procurement for $\mathrm{CO}_{2}$ products and climate policies must be aligned as we are serious about meeting the targets. That being said, utilization might, for instance, compensate for hard-to-control areas such as aviation, and is in any case a logical direction for a carbon-constrained world.

\section{Conclusions and Recommendations}

Increasing atmospheric $\mathrm{CO}_{2}$ concentration is regarded as a major contributor to climate change. Although $\mathrm{CO}_{2}$ capture technologies are relatively mature, the utilization of captured $\mathrm{CO}_{2}$ remains an important challenge which needs much future research. The development of novel LCA and techno-economic tools and benchmark assessments will enable consistent and transparent evaluation of $\mathrm{CO}_{2}$ utilization pathways in the short to medium term. Currently, there exist some limitations to further developing CDU such as energy and water consumption, the use of expensive catalysts, and gas infrastructure issues. In particular, cost-effective $\mathrm{CO}_{2}$ utilization methods are required, and their pilot-scale demonstrations are critical for their commercial deployment. It is evident that the comprehensive introduction of different $\mathrm{CO}_{2}$ utilization methods is beneficial to understanding the mechanisms and choosing appropriate techniques for use of captured $\mathrm{CO}_{2}$. The potential integrated technologies are preferable to make up the present gaps for broad industrial applications. Furthermore, the demonstration of R\&D projects for CDU and analysis of $\mathrm{CO}_{2}$ utilization markets are advantageous to identify the possibility of fullscale deployment of these technologies.

To promote development of the industrial feasibility of CDU technology, economic viability is critical whether this is achieved by means of technical development or policy changes. Thus, future primary research interests should be focused on the areas of CDU and CCS regulations, policy and assessments, and integration of $\mathrm{CO}_{2}$ utilization with other techniques to reduce energy consumption and costs, especially at a larger scale. Meanwhile, in order to improve public awareness of the environmental impacts, public education and 
publicity on CCUS should be emphasized, and international collaborations need to be further enhanced. It should also be emphasized that CDU is not an alternative to CCS, but rather an adjunct and that without CCS we will fail to meet our climate goals. Governments should increase their commitment to CCUS and play a crucial role in promoting its deployment (e.g., tax incentives, financial options, and policies) to maintain the global mean temperature increase below $1.5^{\circ} \mathrm{C}$. Another effective strategy is to encourage private sector investments for larger-scale demonstration programs and commercialization of CDU technologies. In the near future, $\mathrm{CO}_{2}$ may become a resource which will be demanded by different sectors of the global economy and affect the regulation and policy to the $\mathrm{CO}_{2}$ based products market.

\section{Acknowledgements}

Dr. Shu-Yuan Pan would like to acknowledge the Ministry of Science and Technology (MOST) of Taiwan (No. MOST 107-2917-I-564-043) for its financial support. Prof. Jianchao Cai gratefully acknowledges the financial support from the National Natural Science Foundation of China (Nos. 41722403 and 41572116).

\section{References}

[1] Solomon S, Plattner G-K, Knutti R, Friedlingstein P. Irreversible climate change due to carbon dioxide emissions. Proceedings of the National Academy of Sciences. 2009;106:1704-1709.

[2] Figueres C, Le Quéré C, Mahindra A, Bäte O, Whiteman G, Peters G, et al. Emissions are still rising: ramp up the cuts. Nature. 2018;564:27.

[3] National Oceanic and Atmospheric Administration (NOAA). https://www.esrl.noaa.gov/gmd/ccgg/trends/gl_trend.html. 2018. 
[4] BP Energy Economics. BP Energy Outlook 2018. 2018.

[5] IPCC. Global Warming of $1.5^{\circ} \mathrm{C} .2018$.

[6] Yan J, Zhang Z. Carbon Capture, Utilization and Storage (CCUS). Applied Energy. 2019;235:1289-1299.

[7] Global CCS Institute. The Global Status of CCS: 2018. 2018.

[8] Vega F, Baena-Moreno F, Fernández LMG, Portillo E, Navarrete B, Zhang Z. Current status of $\mathrm{CO}_{2}$ chemical absorption research applied to CCS: Towards full deployment at industrial scale. Applied Energy. 2020;260:114313.

[9] USGCRP. Second State of the Carbon Cycle Report (SOCCR2): A Sustained Assessment Report. 2018.

[10] IPCC. Special Report on the Ocean and Cryosphere in a Changing Climate. 2019.

[11] Abanades JC, Rubin ES, Mazzotti M, Herzog HJ. On the climate change mitigation potential of $\mathrm{CO}_{2}$ conversion to fuels. Energy \& Environmental Science. 2017;10:24919.

[12] Meunier N, Chauvy R, Mouhoubi S, Thomas D, De Weireld G. Alternative production of methanol from industrial $\mathrm{CO}_{2}$. Renewable Energy. 2020;146:1192-1203.

[13] Branco JB, Brito PE, Ferreira AC. Methanation of $\mathrm{CO}_{2}$ over nickel-lanthanide bimetallic oxides supported on silica. Chemical Engineering Journal. 2020;380:122465.

[14] Sternberg A, Jens CM, Bardow A. Life cycle assessment of $\mathrm{CO}_{2}$-based C1-chemicals. Green Chemistry. 2017;19:2244-2259.

[15] Kondratenko EV, Mul G, Baltrusaitis J, Larrazábal GO, Pérez-Ramírez J. Status and perspectives of $\mathrm{CO}_{2}$ conversion into fuels and chemicals by catalytic, photocatalytic and electrocatalytic processes. Energy \& Environmental Science. 2013;6:3112-3135.

[16] Costentin C, Drouet S, Robert M, Savéant J-M. A local proton source enhances $\mathrm{CO}_{2}$ 
electroreduction to CO by a molecular Fe catalyst. Science. 2012;338:90-94.

[17] Peterson AA, Nørskov JK. Activity descriptors for $\mathrm{CO}_{2}$ electroreduction to methane on transition-metal catalysts. The Journal of Physical Chemistry Letters. 2012;3:251258.

[18] Back S, Kim H, Jung Y. Selective heterogeneous $\mathrm{CO}_{2}$ electroreduction to methanol. ACS Catalysis. 2015;5:965-971.

[19] Montoya JH, Peterson AA, Nørskov JK, Montoya JH, Peterson AA, Nørskov JK. Insights into $\mathrm{C}-\mathrm{C}$ coupling in $\mathrm{CO}_{2}$ electroreduction on copper electrodes. Chemcatchem. 2013;5:737-742.

[20] Studt F, Sharafutdinov I, Abild-Pedersen F, Elkjær CF, Hummelshøj JS, Dahl S, et al. Discovery of a Ni-Ga catalyst for carbon dioxide reduction to methanol. Nature chemistry. 2014;6:320.

[21] Back S, Min SY, Jung Y. Active sites of $\mathrm{Au}$ and Ag nanoparticle catalysts for $\mathrm{CO}_{2}$ electroreduction to CO. ACS Catalysis. 2015;5:5089-5096.

[22] Gattrell M, Gupta N, Co A. A review of the aqueous electrochemical reduction of $\mathrm{CO}_{2}$ to hydrocarbons at copper. Journal of Electroanalytical Chemistry. 2006;594:1-19.

[23] Nie X, Esopi MR, Janik MJ, Asthagiri A. Selectivity of $\mathrm{CO}_{2}$ reduction on copper electrodes: the role of the kinetics of elementary steps. Angewandte Chemie. 2013;125:2519-2522.

[24] Hansen HA, Varley JB, Peterson AA, Nã Rskov JK. Understanding Trends in the Electrocatalytic Activity of Metals and Enzymes for $\mathrm{CO}_{2}$ Reduction to CO. Journal of Physical Chemistry Letters. 2013;4:388-392.

[25] Cheng MJ, Clark EL, Pham HH, Bell AT, Head-Gordon M. Quantum mechanical screening of single-ttom bimetallic alloys for the selective reduction of $\mathrm{CO}_{2}$ to $\mathrm{C} 1$ hydrocarbons. ACS Catalysis. 2016;6:7769-7777. 
[26] Ma X, Li Z, Achenie LE, Xin H. Machine-Learning-Augmented Chemisorption Model for $\mathrm{CO}_{2}$ Electroreduction Catalyst Screening. Journal of Physical Chemistry Letters. 2015;6:3528.

[27] Ulissi ZW, Tang MT, Xiao J, Liu X, Torelli DA, Karamad M, et al. Machine-learning methods enable exhaustive searches for active bimetallic facets and reveal active site motifs for $\mathrm{CO}_{2}$ reduction. ACS Catalysis. 2017;7:6600-6608.

[28] Li H, Zhang Z, Liu Z. Application of Artificial Neural Networks for Catalysis: A Review. Catalysts. 2017;7:306.

[29] Siahrostami S, Jiang K, Karamad M, Chan K, Wang H, Norskov JK, et al. Theoretical Investigations into Defected Graphene for electrochemical Reduction of $\mathrm{CO}_{2}$. ACS Sustainable Chemistry \& Engineering. 2017;5:11080-11085.

[30] Zhang C, Yang S, Wu J, Liu M, Yazdi S, Ren M, et al. Electrochemical $\mathrm{CO}_{2}$ reduction with atomic iron - dispersed on nitrogen - doped graphene. Advanced Energy Materials. 2018;8:1703487.

[31] Landers AT, Fields M, Torelli DA, Xiao J, Hellstern TR, Francis SA, et al. The predominance of hydrogen evolution on transition metal sulfides and phosphides under $\mathrm{CO}_{2}$ reduction conditions: An experimental and theoretical study. ACS Energy Letters. 2018;3:1450-1457.

[32] Luc W, Collins C, Wang S, Xin H, He K, Kang Y, et al. Ag-Sn bimetallic catalyst with a core-shell structure for $\mathrm{CO}_{2}$ reduction. Journal of the American Chemical Society. 2017;139:1885-1893.

[33] Ngo KT, Mckinnon M, Mahanti B, Narayanan RP, Grills DC, Ertem MZ, et al. Turning on the protonation-first pathway for electrocatalytic $\mathrm{CO}_{2}$ reduction by manganese bipyridyl tricarbonyl complexes. Journal of the American Chemical Society. 2017;139:2604. 
[34] Smith PT, Benke BP, Cao Z, Kim Y, Nichols EM, Kim K, et al. Iron porphyrins embedded into a supramolecular porous organic cage for electrochemical $\mathrm{CO}_{2}$ reduction in water. Angewandte Chemie. 2018;130:9832-9836.

[35] Zhang W, Qin Q, Dai L, Qin R, Zhao X, Chen X, et al. Electrochemical reduction of carbon dioxide to methanol on hierarchical $\mathrm{Pd} / \mathrm{SnO}_{2}$ nanosheets with abundant $\mathrm{Pd}-\mathrm{O}-$ Sn interfaces. Angewandte Chemie International Edition. 2018;57:9475-9479.

[36] Shi C, Chan K, Yoo JS, Norskov JK. Barriers of Electrochemical $\mathrm{CO}_{2}$ Reduction on Transition Metals. Organic Process Research \& Development. 2016;20:1424-1430.

[37] Jovanov ZP, Hansen HA, Varela AS, Malacrida P, Peterson AA, Nørskov JK, et al. Opportunities and challenges in the electrocatalysis of $\mathrm{CO}_{2}$ and $\mathrm{CO}$ reduction using bifunctional surfaces: A theoretical and experimental study of $\mathrm{Au}-\mathrm{Cd}$ alloys. Journal of Catalysis. 2016;343:215-231.

[38] Trindell JA, Clausmeyer J, Crooks RM. Size stability and $\mathrm{H}_{2} / \mathrm{CO}$ selectivity for Au nanoparticles during electrocatalytic $\mathrm{CO}_{2}$ reduction. Journal of the American Chemical Society. 2017;139:16161-16167.

[39] Yadav N, Seidi F, Crespy D, D'Elia V. Polymers based on cyclic carbonates as Trait d'Union between polymer chemistry and sustainable $\mathrm{CO}_{2}$ utilization. ChemSusChem. 2019;12:724-754.

[40] Klaus S, Lehenmeier MW, Anderson CE, Rieger B. Recent advances in $\mathrm{CO}_{2} /$ epoxide copolymerization-New strategies and cooperative mechanisms. Coordination Chemistry Reviews. 2011;255:1460-1479.

[41] Inoue S, Koinuma H, Tsuruta T. Copolymerization of carbon dioxide and epoxide. Journal of Polymer Science Part B: Polymer Letters. 1969;7:287-292.

[42] Lu XB, Darensbourg DJ. Cobalt catalysts for the coupling of $\mathrm{CO}_{2}$ and epoxides to provide polycarbonates and cyclic carbonates. Chemical Society Reviews. 
2012;41:1462-1484.

[43] Trott G, Saini PK, Williams CK. Catalysts for $\mathrm{CO}_{2} /$ epoxide ring-opening copolymerization. Philos Trans A Math Phys Eng Sci. 2016;374:20150085.

[44] Moore DR, Cheng M, Lobkovsky EB, Coates GW. Mechanism of the alternating copolymerization of epoxides and $\mathrm{CO}_{2}$ using $\beta$-diiminate zinc catalysts: evidence for a bimetallic epoxide enchainment. Journal of the American Chemical Society. 2003;125:11911-11924.

[45] Ellis WC, Jung Y, Mulzer M, Di Girolamo R, Lobkovsky EB, Coates GW. Copolymerization of $\mathrm{CO}_{2}$ and meso epoxides using enantioselective $\beta$-diiminate catalysts: a route to highly isotactic polycarbonates. Chemical Science. 2014;5:40044011.

[46] Zhang Y-Y, Yang G-W, Wu G-P. A bifunctional $\beta$-Diiminate Zinc catalyst with $\mathrm{CO}_{2} /$ epoxides copolymerization and RAFT polymerization capacities for versatile block copolymers Construction. Macromolecules. 2018;51:3640-3646.

[47] Quan Z, Min J, Zhou Q, Xie D, Liu J, Wang X, et al. Synthesis and properties of carbon dioxide-epoxides copolymers from rare earth metal catalyst. Macromolecular Symposia: Wiley Online Library; 2003. p. 281-286.

[48] Carpentier J-Fo. Rare-earth complexes supported by tripodal tetradentate bis (phenolate) ligands: a privileged class of catalysts for ring-opening polymerization of cyclic esters. Organometallics. 2015;34:4175-4189.

[49] Mang S, Cooper AI, Colclough ME, Chauhan N, Holmes AB. Copolymerization of $\mathrm{CO}_{2}$ and 1,2-cyclohexene oxide using a $\mathrm{CO}_{2}$-soluble chromium porphyrin catalyst. Macromolecules. 2000;33:303-308.

[50] Lu X-B, He R, Bai C-X. Synthesis of ethylene carbonate from supercritical carbon dioxide/ethylene oxide mixture in the presence of bifunctional catalyst. Journal of 
Molecular Catalysis A: Chemical. 2002;186:1-11.

[51] Gupta K, Sutar AK. Catalytic activities of Schiff base transition metal complexes. Coordination Chemistry Reviews. 2008;252:1420-1450.

[52] Crucianelli M, Saladino R, De Angelis F. Methyltrioxorhenium catalysis in nonconventional solvents: A great catalyst in a safe reaction medium. ChemSusChem: Chemistry \& Sustainability Energy \& Materials. 2010;3:524-540.

[53] Pescarmona PP, Taherimehr M. Challenges in the catalytic synthesis of cyclic and polymeric carbonates from epoxides and $\mathrm{CO}_{2}$. Catalysis Science \& Technology. 2012;2:2169.

[54] Kember MR, Buchard A, Williams CK. Catalysts for $\mathrm{CO}_{2}$ /epoxide copolymerisation. Chem Commun (Camb). 2011;47:141-163.

[55] Qin Y, Sheng X, Liu S, Ren G, Wang X, Wang F. Recent advances in carbon dioxide based copolymers. Journal of $\mathrm{CO}_{2}$ Utilization. 2015;11:3-9.

[56] Taherimehr M, Sertã JPCC, Kleij AW, Whiteoak CJ, Pescarmona PP. New iron pyridylamino - bis (Phenolate) catalyst for converting $\mathrm{CO}_{2}$ into cyclic carbonates and cross - linked polycarbonates. ChemSusChem. 2015;8:1034-1042.

[57] Wang Y, Zhao Y, Ye Y, Peng H, Zhou X, Xie X, et al. A One - Step Route to $\mathrm{CO}_{2}$ Based Block Copolymers by Simultaneous ROCOP of $\mathrm{CO}_{2} /$ Epoxides and RAFT Polymerization of Vinyl Monomers. Angewandte Chemie International Edition. 2018;57:3593-3597.

[58] von der Assen N, Bardow A. Life cycle assessment of polyols for polyurethane production using $\mathrm{CO}_{2}$ as feedstock: insights from an industrial case study. Green Chemistry. 2014;16:3272-3280.

[59] Müller TE, Leitner W, Markewitz P, Kuckshinrichs W. Opportunities for Utilizing and Recycling $\mathrm{CO}_{2}$. In: Kuckshinrichs W, Hake J-F, editors. Carbon Capture, Storage and 
Use: Technical, Economic, Environmental and Societal Perspectives. Cham: Springer International Publishing; 2015. p. 67-100.

[60] Langanke J, Wolf A, Hofmann J, Böhm K, Subhani MA, Müller TE, et al. Carbon dioxide $\left(\mathrm{CO}_{2}\right)$ as sustainable feedstock for polyurethane production. Green Chem. 2014;16:1865-1870.

[61] IPCC. Climate Change and Land: an IPCC special report on climate change, desertification, land degradation, sustainable land management, food security, and greenhouse gas fluxes in terrestrial ecosystems. 2019.

[62] Styring P, Driver JG, Owen R, Makenyire T, McGregor J, Lake JA. Blue Urea: Fertilizer with reduced environmental impact. Frontiers in Energy Research. 2019;7:88.

[63] Gilbert P, Alexander S, Thornley P, Brammer J. Assessing economically viable carbon reductions for the production of ammonia from biomass gasification. Journal of cleaner production. 2014;64:581-589.

[64] Koohestanian E, Sadeghi J, Mohebbi-Kalhori D, Shahraki F, Samimi A. A novel process for $\mathrm{CO}_{2}$ capture from the flue gases to produce urea and ammonia. Energy. 2018;144:279-285.

[65] Barzagli F, Mani F, Peruzzini M. From greenhouse gas to feedstock: formation of ammonium carbamate from $\mathrm{CO}_{2}$ and $\mathrm{NH}_{3}$ in organic solvents and its catalytic conversion into urea under mild conditions. Green Chemistry. 2011;13:1267-1274.

[66] Gerdemann SJ, O'Connor WK, Dahlin DC, Penner LR, Rush H. Ex situ aqueous mineral carbonation. Environmental Science \& Technology. 2007;41:2587-2593.

[67] Pan S-Y, Chiang P-C, Pan W, Kim H. Advances in state-of-art valorization technologies for captured $\mathrm{CO}_{2}$ toward sustainable carbon cycle. Critical Reviews in Environmental Science and Technology. 2018;48:471-534.

[68] Georgakopoulos E, Santos RM, Chiang YW, Manovic V. Influence of process 
parameters on carbonation rate and conversion of steelmaking slags-Introduction of the 'carbonation weathering rate'. Greenhouse Gases: Science and Technology. 2016;6:470-491.

[69] Bui M, Adjiman CS, Bardow A, Anthony EJ, Boston A, Brown S, et al. Carbon capture and storage (CCS): the way forward. Energy \& Environmental Science. 2018;11:10621176.

[70] Keith DW, Holmes G, Angelo DS, Heidel K. A process for capturing $\mathrm{CO}_{2}$ from the atmosphere. Joule. 2018;2:1573-1594.

[71] Pei SL, Pan SY, Li YM, Chiang PC. Environmental Benefit Assessment for the Carbonation Process of Petroleum Coke Fly Ash in a Rotating Packed Bed. Environ Sci Technol. 2017;51:10674-10681.

[72] Xie H, Yue H, Zhu J, Liang B, Li C, Wang Y, et al. Scientific and engineering progress in $\mathrm{CO}_{2}$ mineralization using industrial waste and natural minerals. Engineering. $2015 ; 1: 150-157$.

[73] Pan SY, Chiang PC, Chen YH, Tan CS, Chang EE. Ex Situ $\mathrm{CO}_{2}$ capture by carbonation of steelmaking slag coupled with metalworking wastewater in a rotating packed bed. Environ Sci Technol. 2013;47:3308-33015.

[74] Jiang Y, Ling T-C, Shi C, Pan S-Y. Characteristics of steel slags and their use in cement and concrete-A review. Resource, Conservation and Recycling. 2018;136:187-197.

[75] Chang EE, Pan SY, Yang L, Chen YH, Kim H, Chiang PC. Accelerated carbonation using municipal solid waste incinerator bottom ash and cold-rolling wastewater: Performance evaluation and reaction kinetics. Waste Manag. 2015;43:283-292.

[76] Mohamed HA, Campos L. Oil Shale Ash Utilization in Industrial Processes as an Alternative Raw Material: Royal Institute of Technology; 2016.

[77] Leben K, Mõtlep R, Paaver P, Konist A, Pihu T, Paiste P, et al. Long-term mineral 
transformation of Ca-rich oil shale ash waste. Science of The Total Environment. 2019;658:1404-1415.

[78] Ben Ghacham A, Cecchi E, Pasquier LC, Blais JF, Mercier G. CO 2 sequestration using waste concrete and anorthosite tailings by direct mineral carbonation in gas-solid-liquid and gas-solid routes. J Environ Manage. 2015;163:70-77.

[79] Meng YZ, Ling TC, Mo KH. Recycling of wastes for value-added applications in concrete blocks: An overview. Resources Conservation and Recycling. 2018;138:298312.

[80] Yadav VS, Prasad M, Khan J, Amritphale SS, Singh M, Raju CB. Sequestration of carbon dioxide $\left(\mathrm{CO}_{2}\right)$ using red mud. Journal of Hazardous Materials. 2010;176:10441050.

[81] Harrison AL, Power IM, Dipple GM. Accelerated carbonation of brucite in mine tailings for carbon sequestration. Environ Sci Technol. 2013;47:126-134.

[82] Perez-Lopez R, Castillo J, Quispe D, Nieto JM. Neutralization of acid mine drainage using the final product from $\mathrm{CO}_{2}$ emissions capture with alkaline paper mill waste. Journal of Hazardous Materials. 2010;177:762-772.

[83] Perez-Lopez R, Montes-Hernandez G, Nieto JM, Renard F, Charlet L. Carbonation of alkaline paper mill waste to reduce $\mathrm{CO}_{2}$ greenhouse gas emissions into the atmosphere. Applied Geochemistry. 2008;23:2292-2300.

[84] Pan SY, Chang EE, Kim H, Chen YH, Chiang PC. Validating carbonation parameters of alkaline solid wastes via integrated thermal analyses: Principles and applications. J Hazard Mater. 2016;307:253-262.

[85] Pan S-Y, Chiang A, Chang E-E, Lin Y-P, Kim H, Chiang P-C. An innovative approach to integrated carbon mineralization and waste utilization: A review. Aerosol and Air Quality Research. 2015;15:1072-1091. 
[86] Steinour HH. Some effects of carbon dioxide on mortars and concrete - Discussion. J Am Concr Inst 1959;30:905-7.

[87] Pan S-Y, Chang EE, Chiang P-C. $\mathrm{CO}_{2}$ capture by accelerated carbonation of alkaline wastes: A review on its principles and applications. Aerosol and Air Quality Research. 2012;12:770-791.

[88] Teir S. Fixation of carbon dioxide by producing carbonates from minerals and steelmaking slags: Helsinki University of Technology; 2008.

[89] Huijgen WJJ, Comans RNJ. Carbonation of steel slag for $\mathrm{CO}_{2}$ sequestration: Leaching of products and reaction mechanisms. Environmental Science \& Technology. 2006;40:2790-2796.

[90] Jia L, Anthony EJ, Lin W, Ruan Y, Gora D. Carbonation of magnesium silicate minerals: an experimental study. The Canadian Journal of Chemical Engineering. 2004;82:1289-1295.

[91] Turvey CC, Wilson SA, Hamilton JL, Tait AW, McCutcheon J, Beinlich A, et al. Hydrotalcites and hydrated Mg-carbonates as carbon sinks in serpentinite mineral wastes from the Woodsreef chrysotile mine, New South Wales, Australia: Controls on carbonate mineralogy and efficiency of $\mathrm{CO}_{2}$ air capture in mine tailings. International Journal of Greenhouse Gas Control. 2018;79:38-60.

[92] Pan SY, Chen YH, Chen CD, Shen AL, Lin M, Chiang PC. High-gravity carbonation process for enhancing $\mathrm{CO}_{2}$ fixation and utilization exemplified by the steelmaking industry. Environ Sci Technol. 2015;49:12380-12387.

[93] Li Y, Pei S, Pan S-Y, Chiang P-C, Lu C, Ouyang T. Carbonation and utilization of basic oxygen furnace slag coupled with concentrated water from electrodeionization. Journal of $\mathrm{CO}_{2}$ Utilization. 2018;25:46-55.

[94] Fischer S, Liebschera A. Mineral solubilities in $\mathrm{CO}_{2}$-saturated $\mathrm{NaCl}$ brine systems. 
Procedia Earth and Planetary Science. 2013;7:260-263.

[95] Xie H, Wang Y, He Y, Gou M, Liu T, Wang J, et al. Generation of electricity from $\mathrm{CO}_{2}$ mineralization: Principle and realization. Science China Technological Sciences. 2014;57:2335-2343.

[96] IEA. Mineralisation - Carbonation and Enhanced Weathering. International Energy Agency; 2013.

[97] Huijgen W, Comans R, Witkamp G. Cost evaluation of $\mathrm{CO}_{2}$ sequestration by aqueous mineral carbonation. Energy Conversion and Management. 2007;48:1923-1935.

[98] Huijgen WJJ, Ruijg GJ, Comans RNJ, Witkamp GJ. Energy consumption and net $\mathrm{CO}_{2}$ sequestration of aqueous mineral carbonation. Industrial \& Engineering Chemistry Research. 2006;45:9184-9194.

[99] Pan S-Y, Lorente Lafuente AM, Chiang P-C. Engineering, environmental and economic performance evaluation of high-gravity carbonation process for carbon capture and utilization. Applied Energy. 2016;170:269-277.

[100] Cockerill R. Joint venture to produce food-grade $\mathrm{CO}_{2}$ in China. Gasworld2013.

[101] Stewart JR, Haszeldine RS. Carbon Accounting for Carbon Dioxide Enhanced Oil Recovery. SCCS; 2014.

[102] Raventós M, Duarte S, Alarcón R. Application and possibilities of supercritical $\mathrm{CO}_{2}$ extraction in food processing industry: an overview. Food Science and Technology International. 2002;8:269-284.

[103] Boyère C, Jérôme C, Debuigne A. Input of supercritical carbon dioxide to polymer synthesis: An overview. European Polymer Journal. 2014;61:45-63.

[104] Ghosh M, Srivastava S, Mishra HN. Advent of clean and green technology for preparation of low-cholesterol dairy cream powder: supercritical fluid extraction process. Food Quality and Safety. 2018;2:205-211. 
[105] Palmer M, Ting S. Applications for supercritical fluid technology in food processing. Food Chemistry. 1995;4:345-352.

[106] Brunner G. Supercritical fluids: technology and application to food processing. Journal of Food Engineering. 2005;67:21-33.

[107] Reverchon E, Porta GD, Senatore F. Supercritical $\mathrm{CO}_{2}$ extraction and fractionation of lavender essential oil and waxes. Journal of Agricultural and Food Chemistry. 1995;43:1654-1658.

[108] Reverchon E. Supercritical fluid extraction and fractionation of essential oils and related products. The Journal of Supercritical Fluids. 1997;10:1-37.

[109] Oliveira R, Fátima Rodrigues M, Gabriela Bernardo - Gil M. Characterization and supercritical carbon dioxide extraction of walnut oil. Journal of the American Oil Chemists' Society. 2002;79:225-230.

[110] Liu S, Yang F, Zhang C, Ji H, Hong P, Deng C. Optimization of process parameters for supercritical carbon dioxide extraction of Passiflora seed oil by response surface methodology. The Journal of Supercritical Fluids. 2009;48:9-14.

[111] Sánchez-Vicente Y, Cabañas A, Renuncio JAR, Pando C. Supercritical fluid extraction of peach (Prunus persica) seed oil using carbon dioxide and ethanol. The Journal of Supercritical Fluids. 2009;49:167-173.

[112] King J, Johnson J, Orton W, McKeith F, O'Connor P, Novakofski J, et al. Fat and cholesterol content of beef patties as affected by supercritical $\mathrm{CO}_{2}$ extraction. Journal of Food Science. 1993;58:950-952.

[113] Sahena F, Zaidul I, Jinap S, Karim A, Abbas K, Norulaini N, et al. Application of supercritical $\mathrm{CO}_{2}$ in lipid extraction-A review. Journal of Food Engineering. 2009;95:240-253.

[114] Chao RR, Mulvaney SJ, Sanson DR, HSIEH FH, Tempesta MS. Supercritical $\mathrm{CO}_{2}$ 
extraction of annatto (Bixa orellana) pigments and some characteristics of the color extracts. Journal of Food Science. 1991;56:80-83.

[115] Arlorio M, Coïsson J, Travaglia F, Varsaldi F, Miglio G, Lombardi G, et al. Antioxidant and biological activity of phenolic pigments from Theobroma cacao hulls extracted with supercritical $\mathrm{CO}_{2}$. Food Research International. 2005;38:1009-1014.

[116] Díaz-Reinoso B, Moure A, Domínguez H, Parajó JC. Supercritical $\mathrm{CO}_{2}$ extraction and purification of compounds with antioxidant activity. Journal of Agricultural and Food Chemistry. 2006;54:2441-2469.

[117] Zeković Z, Pfaf-Šovljanski I, Grujić O. Supercritical fluid extraction of hops. Journal of the Serbian Chemical Society. 2007;72:81-87.

[118] Kupski SC, Klein EJ, da Silva EA, Palú F, Guirardello R, Vieira MGA. Mathematical modeling of supercritical $\mathrm{CO}_{2}$ extraction of hops (Humulus lupulus L.). The Journal of Supercritical Fluids. 2017;130:347-356.

[119] Park H, Choi H, Lee S, Park K, Choi S, Kim K. Effect of mass transfer on the removal of caffeine from green tea by supercritical carbon dioxide. Journal of Supercritical Fluids. 2007;42:205-211.

[120] Bermejo DV, Ibáñez E, Reglero G, Fornari T. Effect of cosolvents (ethyl lactate, ethyl acetate and ethanol) on the supercritical $\mathrm{CO}_{2}$ extraction of caffeine from green tea. The Journal of Supercritical Fluids. 2016;107:507-512.

[121] Ilgaz S, Sat IG, Polat A. Effects of processing parameters on the caffeine extraction yield during decaffeination of black tea using pilot-scale supercritical carbon dioxide extraction technique. Journal of Food Science and Engineering. 2018;55:1407-1415.

[122] Conde-Hernández LA, Espinosa-Victoria JR, Trejo A, Guerrero-Beltrán JÁ. CO CO- $^{-}$ supercritical extraction, hydrodistillation and steam distillation of essential oil of rosemary (Rosmarinus officinalis). Journal of Food Engineering. 2017;200:81-86. 
[123] Rai A, Mohanty B, Bhargava R. Modeling and response surface analysis of supercritical extraction of watermelon seed oil using carbon dioxide. Separation and Purification Technology. 2015;141:354-365.

[124] Lenucci MS, De Caroli M, Marrese PP, Iurlaro A, Rescio L, Böhm V, et al. Enzymeaided extraction of lycopene from high-pigment tomato cultivars by supercritical carbon dioxide. Food Chemistry. 2015;170:193-202.

[125] Dutta S, Bhattacharjee P. Enzyme-assisted supercritical carbon dioxide extraction of black pepper oleoresin for enhanced yield of piperine-rich extract. Journal of Bioscience and Bioengineering. 2015;1:17-23.

[126] Reátegui JLP, da Fonseca Machado AP, Barbero GF, Rezende CA, Martínez J. Extraction of antioxidant compounds from blackberry (Rubus sp.) bagasse using supercritical $\mathrm{CO}_{2}$ assisted by ultrasound. The Journal of Supercritical Fluids. 2014;94:223-233.

[127] Santos P, Aguiar AC, Barbero GF, Rezende CA, Martínez J. Supercritical carbon dioxide extraction of capsaicinoids from malagueta pepper (Capsicum frutescens $\mathrm{L}$.) assisted by ultrasound. Ultrasonics Sonochemistry. 2015;22:78-88.

[128] Mustapa AN, Martin Á, Mato RB, Cocero MJ. Extraction of phytocompounds from the medicinal plant Clinacanthus nutans Lindau by microwave-assisted extraction and supercritical carbon dioxide extraction. Industrial Crops and Products. 2015;74:83-94.

[129] Putnik P, Kovačević DB, Penić M, Fegeš M, Dragović-Uzelac V. Microwaveassisted extraction (MAE) of dalmatian sage leaves for the optimal yield of polyphenols: HPLC-DAD identification and quantification. Food Analytical Methods. 2016;9:23852394.

[130] Yusoff N, Leo C. Microwave assisted extraction of defatted roselle (Hibiscus sabdariffa L.) seed at subcritical conditions with statistical analysis. Journal of Food Quality. 2017;2017. 
[131] Chisti Y. Biodiesel from microalgae. Biotechnology Advances. 2007;25:294-306.

[132] Vuppaladadiyam AK, Yao JG, Florin N, George A, Wang X, Labeeuw L, et al. Impact of flue gas compounds on microalgae and mechanisms for carbon assimilation and utilization. ChemSusChem. 2018;11:334-355.

[133] Mohler D, Wilson MH, Kesner S, Schambach JY, Vaughan D, Frazar M, et al. Beneficial re-use of industrial $\mathrm{CO}_{2}$ emissions using microalgae: Demonstration assessment and biomass characterization. Bioresource technology. 2019;293:122014.

[134] Zhao B, Su Y. Process effect of microalgal-carbon dioxide fixation and biomass production: A review. Renewable and Sustainable Energy Reviews. 2014;31:121-132.

[135] Singh SK, Sundaram S, Sinha S, Rahman MA, Kapur S. Recent advances in $\mathrm{CO}_{2}$ uptake and fixation mechanism of cyanobacteria and microalgae. Critical Reviews in Environmental Science and Technology. 2016;46:1297-1323.

[136] Adamczyk M, Lasek J, Skawińska A. $\mathrm{CO}_{2}$ biofixation and growth kinetics of Chlorella vulgaris and Nannochloropsis gaditana. Applied Biochemistry and Biotechnology. 2016;179:1248-1261.

[137] Mondal M, Goswami S, Ghosh A, Oinam G, Tiwari O, Das P, et al. Production of biodiesel from microalgae through biological carbon capture: a review. 3 Biotech. 2017;7:99.

[138] Chiang C-L, Lee C-M, Chen P-C. Utilization of the cyanobacteria Anabaena sp. CH1 in biological carbon dioxide mitigation processes. Bioresource Technology. 2011;102:5400-5405.

[139] Sydney EB, Sturm W, de Carvalho JC, Thomaz-Soccol V, Larroche C, Pandey A, et al. Potential carbon dioxide fixation by industrially important microalgae. Bioresource Technology. 2010;101:5892-5896.

[140] Thawechai T, Cheirsilp B, Louhasakul Y, Boonsawang P, Prasertsan P. Mitigation of 
carbon dioxide by oleaginous microalgae for lipids and pigments production: Effect of light illumination and carbon dioxide feeding strategies. Bioresource Technology. 2016;219:139-149.

[141] Tang D, Han W, Li P, Miao X, Zhong J. $\mathrm{CO}_{2}$ biofixation and fatty acid composition of Scenedesmus obliquus and Chlorella pyrenoidosa in response to different $\mathrm{CO}_{2}$ levels. Bioresource Technology. 2011;102:3071-3076.

[142] Kumar K, Banerjee D, Das D. Carbon dioxide sequestration from industrial flue gas by Chlorella sorokiniana. Bioresource Technology. 2014;152:225-233.

[143] Ryu HJ, Oh KK, Kim YS. Optimization of the influential factors for the improvement of $\mathrm{CO}_{2}$ utilization efficiency and $\mathrm{CO}_{2}$ mass transfer rate. Journal of Industrial and Engineering Chemistry. 2009;15:471-475.

[144] Fan L-H, Zhang Y-T, Zhang L, Chen H-L. Evaluation of a membrane-sparged helical tubular photobioreactor for carbon dioxide biofixation by Chlorella vulgaris. Journal of Membrane Science. 2008;325:336-345.

[145] Cheng L, Zhang L, Chen H, Gao C. Carbon dioxide removal from air by microalgae cultured in a membrane-photobioreactor. Separation and Purification Technology. 2006;50:324-329.

[146] Lam MK, Lee KT. Effect of carbon source towards the growth of Chlorella vulgaris for $\mathrm{CO}_{2}$ bio-mitigation and biodiesel production. International Journal of Greenhouse Gas Control. 2013;14:169-176.

[147] Yeh KL, Chang JS. Nitrogen starvation strategies and photobioreactor design for enhancing lipid content and lipid production of a newly isolated microalga Chlorella vulgaris ESP - 31: Implications for biofuels. Biotechnology Journal. 2011;6:13581366.

[148] Chae SR, Hwang EJ, Shin HS. Single cell protein production of Euglena gracilis and 
carbon dioxide fixation in an innovative photo-bioreactor. Bioresource Technology. 2006;97:322-329.

[149] de Morais MG, Costa JA. Biofixation of carbon dioxide by Spirulina sp. and Scenedesmus obliquus cultivated in a three-stage serial tubular photobioreactor. Journal of Biotechnology. 2007;129:439-445.

[150] Ho S-H, Chen W-M, Chang J-S. Scenedesmus obliquus CNW-N as a potential candidate for $\mathrm{CO}_{2}$ mitigation and biodiesel production. Bioresource Technology. 2010;101:8725-8730.

[151] Ho S-H, Chen C-Y, Yeh K-L, Chen W-M, Lin C-Y, Chang J-S. Characterization of photosynthetic carbon dioxide fixation ability of indigenous Scenedesmus obliquus isolates. Biochemical Engineering Journal. 2010;53:57-62.

[152] Nayak M, Karemore A, Sen R. Performance evaluation of microalgae for concomitant wastewater bioremediation, $\mathrm{CO}_{2}$ biofixation and lipid biosynthesis for biodiesel application. Algal Research. 2016;16:216-223.

[153] Chang H, Quan X, Zhong N, Zhang Z, Lu C, Li G, et al. High-efficiency nutrients reclamation from landfill leachate by microalgae Chlorella vulgaris in membrane photobioreactor for bio-lipid production. Bioresource Technology. 2018;266:374-381.

[154] Tsai DD-W, Ramaraj R, Chen PH. Growth condition study of algae function in ecosystem for $\mathrm{CO}_{2}$ bio-fixation. Journal of Photochemistry and Photobiology B: Biology. 2012;107:27-34.

[155] Miyachi S, Iwasaki I, Shiraiwa Y. Historical perspective on microalgal and cyanobacterial acclimation to low-and extremely high- $\mathrm{CO}_{2}$ conditions. Photosynthesis Research. 2003;77:139-153.

[156] Sakai N, Sakamoto Y, Kishimoto N, Chihara M, Karube I. Chlorella strains from hot springs tolerant to high temperature and high $\mathrm{CO}_{2}$. Energy Conversion and 
Management. 1995;36:693-696.

[157] Iwasaki I, Hu Q, Kurano N, Miyachi S. Effect of extremely high- $\mathrm{CO}_{2}$ stress on energy distribution between photosystem I and photosystem II in a 'high- $\mathrm{CO}_{2}$ ' tolerant green alga, Chlorococcum littorale and the intolerant green alga Stichococcus bacillaris. Journal of Photochemistry and Photobiology B: Biology. 1998;44:184-190.

[158] Zhang K, Kurano N, Miyachi S. Outdoor culture of a cyanobacterium with a vertical flat-plate photobioreactor: effects on productivity of the reactor orientation, distance setting between the plates, and culture temperature. Applied Microbiology and Biotechnology. 1999;52:781-786.

[159] Wang B, Wang J, Zhang W, Meldrum DR. Application of synthetic biology in cyanobacteria and algae. Frontiers in Microbiology. 2012;3:344.

[160] Kampman N, Busch A, Bertier P, Snippe J, Hangx S, Pipich V, et al. Observational evidence confirms modelling of the long-term integrity of $\mathrm{CO}_{2}$-reservoir caprocks. Nature Communications. 2016;7:12268.

[161] Alcalde J, Flude S, Wilkinson M, Johnson G, Edlmann K, Bond CE, et al. Estimating geological $\mathrm{CO}_{2}$ storage security to deliver on climate mitigation. Nat Commun. 2018;9:2201.

[162] Middleton R, Viswanathan $\mathrm{H}$, Currier R, Gupta R. $\mathrm{CO}_{2}$ as a fracturing fluid: Potential for commercial-scale shale gas production and $\mathrm{CO}_{2}$ sequestration. Energy Procedia. 2014;63:7780-7784.

[163] Al Adasani A, Bai B. Analysis of EOR projects and updated screening criteria. Journal of Petroleum Science and Engineering. 2011;79:10-24.

[164] Singh $\mathrm{H}$. Impact of four different $\mathrm{CO}_{2}$ injection schemes on extent of reservoir pressure and saturation. Advances in Geo-Energy Research. 2018;2:305-318.

[165] Madani M, Zargar G, Takassi MA, Daryasafar A, Wood DA, Zhang Z. Fundamental 
investigation of an environmentally-friendly surfactant agent for chemical enhanced oil recovery. Fuel. 2019;238:186-197.

[166] Stewart RJ, Johnson G, Heinemann N, Wilkinson M, Haszeldine RS. Low carbon oil production: Enhanced oil recovery with $\mathrm{CO}_{2}$ from North Sea residual oil zones. International Journal of Greenhouse Gas Control. 2018;75:235-242.

[167] Scott V, Gilfillan S, Markusson N, Chalmers H, Haszeldine RS. Last chance for carbon capture and storage. Nature Climate Change. 2012;3:105-111.

[168] Aminu MD, Nabavi SA, Rochelle CA, Manovic V. A review of developments in carbon dioxide storage. Applied Energy. 2017;208:1389-1419.

[169] Hepburn C, Adlen E, Beddington J, Carter EA, Fuss S, Mac Dowell N, et al. The technological and economic prospects for $\mathrm{CO}_{2}$ utilization and removal. Nature. 2019;575:87-97.

[170] Sheng JJ. Enhanced oil recovery in shale reservoirs by gas injection. Journal of Natural Gas Science and Engineering. 2015;22:252-259.

[171] Foroozesh J, Abdalla AIM, Zhang Z. Pore network modeling of shale gas reservoirs: Gas desorption and slip flow effects. Transport in Porous Media. 2019;126:633-653.

[172] Godec M, Koperna G, Petrusak R, Oudinot A. Enhanced gas recovery and $\mathrm{CO}_{2}$ storage in gas shales: A summary review of its status and potential. Energy Procedia. 2014;63:5849-5857.

[173] Zhou J, Liu G, Jiang Y, Xian X, Liu Q, Zhang D, et al. Supercritical carbon dioxide fracturing in shale and the coupled effects on the permeability of fractured shale: An experimental study. Journal of Natural Gas Science and Engineering. 2016;36:369377.

[174] Jiang J, Younis RM. Compositional modeling of enhanced hydrocarbons recovery for fractured shale gas-condensate reservoirs with the effects of capillary pressure and 
multicomponent mechanisms. Journal of Natural Gas Science and Engineering. 2016;34:1262-1275.

[175] Zhou J, Hu N, Xian X, Zhou L, Tang J, Yong Kang, et al. Supercritical $\mathrm{CO}_{2}$ fracking for enhanced shale gas recovery and $\mathrm{CO}_{2}$ sequestration: results, status and future challenges. Advances in Geo-Energy Research. 2019;3:207-224.

[176] Oldenburg C, Pruess K, Benson SM. Process modeling of $\mathrm{CO}_{2}$ injection into natural gas reservoirs for carbon sequestration and enhanced gas recovery. Energy \& Fuels. 2001;15:293-298.

[177] Kim TH, Cho J, Lee KS. Evaluation of $\mathrm{CO}_{2}$ injection in shale gas reservoirs with multi-component transport and geomechanical effects. Applied Energy. 2017;190:1195-1206.

[178] Pathak M, Huang H, Meakin P, Deo M. Molecular investigation of the interactions of carbon dioxide and methane with kerogen: Application in enhanced shale gas recovery. Journal of Natural Gas Science and Engineering. 2018;51:1-8.

[179] Liu F, Ellett K, Xiao Y, Rupp JA. Assessing the feasibility of $\mathrm{CO}_{2}$ storage in the New Albany Shale (Devonian-Mississippian) with potential enhanced gas recovery using reservoir simulation. International Journal of Greenhouse Gas Control. 2013;17:111126.

[180] Yin H, Zhou J, Jiang Y, Xian X, Liu Q. Physical and structural changes in shale associated with supercritical $\mathrm{CO}_{2}$ exposure. Fuel. 2016;184:289-303.

[181] Sun H, Yao J, Gao S, Fan D, Wang C, Sun Z. Numerical study of $\mathrm{CO}_{2}$ enhanced natural gas recovery and sequestration in shale gas reservoirs. International Journal of Greenhouse Gas Control. 2013;19:406-419.

[182] Liu Q, Liu W, Hu J, Wang L, Gao J, Liang B, et al. Energy-efficient mineral carbonation of blast furnace slag with high value-added products. Journal of Cleaner 
Production. 2018;197:242-252.

[183] Sun Y, Zhao Y, Yuan L. CO2-ECBM in coal nanostructure: Modelling and simulation. Journal of Natural Gas Science and Engineering. 2018;54:202-215.

[184] Brown S, Mahgerefteh H, Martynov S, Sundara V, Mac Dowell N. A multi-source flow model for CCS pipeline transportation networks. International Journal of Greenhouse Gas Control. 2015;43:108-114.

[185] Rösch C, Roßmann M, Weickert S. Microalgae for integrated food and fuel production. Gcb Bioenergy. 2019;11:326-334.

[186] Luu MT, Milani D, Abbas A. Analysis of $\mathrm{CO}_{2}$ utilization for methanol synthesis integrated with enhanced gas recovery. Journal of Cleaner Production. 2016;112:35403554.

[187] Ateka A, Pérez-Uriarte P, Gamero M, Ereña J, Aguayo AT, Bilbao J. A comparative thermodynamic study on the $\mathrm{CO}_{2}$ conversion in the synthesis of methanol and of DME. Energy. 2017;120:796-804.

[188] von der Assen N, Voll P, Peters M, Bardow A. Life cycle assessment of $\mathrm{CO}_{2}$ capture and utilization: a tutorial review. Chem Soc Rev. 2014;43:7982-7994.

[189] Cuéllar-Franca RM, Azapagic A. Carbon capture, storage and utilisation technologies: A critical analysis and comparison of their life cycle environmental impacts. Journal of $\mathrm{CO}_{2}$ utilization. 2015;9:82-102.

[190] Artz J, Müller TE, Thenert K, Kleinekorte J, Meys R, Sternberg A, et al. Sustainable conversion of carbon dioxide: an integrated review of catalysis and life cycle assessment. Chemical reviews. 2017;118:434-504.

[191] Pérez-Fortes M, Bocin-Dumitriu A, Tzimas E. $\mathrm{CO}_{2}$ Utilization Pathways: TechnoEconomic Assessment and Market Opportunities. Energy Procedia. 2014;63:79687975. 
[192] NETL. Carbon Storage Technology Program Plan. 2014.

[193] United States Government Accountability Office. Advanced Fossil Energy. 2018.

[194] Edwards RW, Celia MA. Infrastructure to enable deployment of carbon capture, utilization, and storage in the United States. Proceedings of the National Academy of Sciences. 2018;115:E8815-E24.

[195] Xie H, Li X, Fang Z, Wang Y, Li Q, Shi L, et al. Carbon geological utilization and storage in China: current status and perspectives. Acta Geotechnica. 2013;9:7-27.

[196] Global CCS Institute. Carbon capture and storage in de-carbonising the Chinese economy. 2018.

[197] Department for Business EIS. UK carbon capture, usage and storage. 2018.

[198] Department for Business EIS. UK's largest carbon capture project to prevent equivalent of 22,000 cars' emissions from polluting the atmosphere from 2021. 2019.

[199] Geosciences Australia. International Carbon Capture and Storage Project. 2019.

[200] Global CCS Institute. Policy priorities to incentivise large scale deployment of CCS. 2019.

[201] Ministry of Petroleum and Energy. The Goverment proposes state contribution for funding of CCS exploration well. 2019.

[202] Marcu A, Zachmann G, Holguera SG, Stoefs W. Developing the EU Long-Term Climate Strategy. 2018.

[203] Mennicken L, Janz A, Roth S. The German R\&D program for $\mathrm{CO}_{2}$ utilizationinnovations for a green economy. Environmental Science and Pollution Research. 2016;23:11386-11392.

[204] Leung DYC, Caramanna G, Maroto-Valer MM. An overview of current status of carbon dioxide capture and storage technologies. Renewable and Sustainable Energy 
Reviews. 2014;39:426-443.

[205] The Global CCS Institute. https://status.globalccsinstitute.com/projects/co2utilisation-projects. 2018.

[206] Folger P. Carbon capture and sequestration (CCS) in the United States. 2017.

[207] Gaurina-Međimurec N, Mavar KN. Carbon Capture and Storage (CCS): Geological Sequestration of $\mathrm{CO}_{2} . \mathrm{CO}_{2}$ Sequestration: IntechOpen; 2019.

[208] Warren P. The role of climate finance beyond renewables: demand-side management and carbon capture, usage and storage. Climate Policy. 2019:1-17.

[209] Technavio. Global $\mathrm{CO}_{2}$ Market 2018-2022. 2018.

[210] Le Quéré C, Andrew RM, Friedlingstein P, Sitch S, Hauck J, Pongratz J, et al. Global carbon budget 2018. Earth System Science Data. 2018;10:2141-2194.

[211] Jackson R, Le Quéré C, Andrew R, Canadell J, Korsbakken J, Liu Z, et al. Global energy growth is outpacing decarbonization. Environmental Research Letters. 2018;13:120401.

[212] Roh K, Lee JH, Gani R. A methodological framework for the development of feasible $\mathrm{CO}_{2}$ conversion processes. International Journal of Greenhouse Gas Control. $2016 ; 47: 250-265$.

[213] Initiative CSaTGC. Global Roadmap for Implementing $\mathrm{CO}_{2}$ Utilization. 2016.

[214] Chauvy R, Meunier N, Thomas D, De Weireld G. Selecting emerging $\mathrm{CO}_{2}$ utilization products for short-to mid-term deployment. Applied Energy. 2019;236:662-680.

[215] Global CCS Institute. Is the world ready for carbon capture and storage? 2018. 